\title{
El modo de producción asiático: Consideraciones en torno al Egipto antiguo*
}

Andrea Zingarelli

Universidad Nacional de La Plata, Argentina

Fecha de recepción: 14 de julio de 2019. Fecha de aceptación: 28 de agosto de 2019.

\section{Resumen}

En este artículo se expondrá la vigencia de las proposiciones de Marx y Engels, con sus contradicciones y sus variaciones en el tiempo, respecto del modo de producción asiático. En particular, trataremos la conexión con el proceso histórico en el Antiguo Egipto, especialmente en relación con la organización estatal. Analizaremos, en parte también, cómo esas elaboraciones de los autores alemanes fueron recibidas y transformadas por la historiografía marxista más relevante.

\section{The Asian mode of production: Considerations around ancient Egypt}

\begin{abstract}
This article studies the validity of Marx and Engels' propositions -with their contradictions and variations through time- regarding the Asiatic Mode of Production. In particular, the relation to historical processes in Ancient Egypt, especially concerning the state organization, will be studied. The article will also analyze how these elaborations by the German scholars were received and transformed by the main exponents of Marxist historiography.
\end{abstract}

\footnotetext{
"Versión traducida -con cierta bibliografía adaptada y actualizada- de "Asiatic Mode of Production: Considerations on Ancient Egypt” en: L. da Graca y A. Zingarelli (eds.), Studies on Pre-Capitalist Modes of Production. Brill, Leiden, 2015: 27-76.
}

Palabras clave

modo de producción asiático Antiguo Egipto

Estado

Karl Marx

Keywords

Asiatic Mode of Production Ancient Egypt State Karl Marx 
1. Es difícil superar el capítulo de O'Leary (1989) por su agudeza y reflexión en su análisis cronológico de los escritos de Marx y Engels y los problemas de interpretación de los mismos; de todos modos nuestra intención dista de pretender realizar un balance historiográfico en sí mismo. Reseña de libro de O'Leary en Loone (1995).

2. Mucho más fructífero sería plantear estos problemas a partir de la historia comparada pero carezco de los conocimientos y destrezas específicas. (continúa en página 107)

3. O’Leary (1989:132) señala los múltiples propósitos ideológicos y teóricos que recorren

las publicaciones de Marx y Engels sobre el tema.

4. También en El Capital, volumen I, sección 4 cuando trata sobre el fetichismo de las mercancías dice:

"En los modos de producción paleoasiático, antiguo, etc., (continúa en página 107)

5. Estos dos últimos atributos son enfatizados en las cartas cruzadas entre Marx y Engels de junio de 1853 (Marx, 1983 [1853]: 330 ss., Engels, 1983 [1853]: 335 ss.), así como en el artículo escrito por Marx en el New York Daily Tribune también en 1853 (Marx, 1979 [1853]:125-129). Volveremos más adelante sobre ello.

6. Por ejemplo Bartra (1983 [1969]: 21-34) despliega la evolución de conceptos asociados, en particular el de despotismo oriental desde Platón y Aristóteles hasta Richard Jones y Hegel. (continúa en página 107)

7. Fue Anderson (1998 [1974]: 568) quien sugirió "dejar que a este concepto (el de modo asiático de producción) le sea dado el entierro decente que merece". (continúa en página 107)

8. Especialmente Sofri (1969: 81-103) sobre el período anterior. Una discusión sobre el modo de producción asiático y la extensión de esta categoría al Oriente contemporáneo se da entre distintos estudiosos en Tiflis

(continúa en página 107)

9. En 1957 fue publicado por Yale University Press, New Haven. La versión en español que utilizamos es la publicada en 1966. (continúa en página 108)

10. Es destacable que, como Ilama la atención O'Leary (1989: 139), Wittfogel subtitule uno de

los capítulos "Marx, Engels y

enin aceptan el modo asiáti-

co", dado que Marx mismo crea

esa noción, la idea que él debió aceptarla es poco generosa.
En este artículo se expondrá la vigencia de las proposiciones de Marx y Engels -con sus contradicciones y sus variaciones en el tiempo- respecto del modo de producción asiático, ${ }^{1}$ en conexión con el proceso histórico de un estado antiguo. Analizaremos, en parte también, cómo esas elaboraciones de los autores alemanes fueron recibidas y transformadas por la historiografía marxista más relevante. Con más precisión, es de nuestro interés analizar el modo de producción asiático a partir en particular de las relaciones de producción dominantes en el Egipto faraónico. ${ }^{2}$ Este objetivo de indagación no implica un mero recurso o apelación a los "hechos" de la historia egipcia en el sentido empirista que fuertemente criticaban Hindess y Hirst (1975: 1-20) sino un recurso a la abstracción pero del proceso de la historia, no de una elaboración ideal carente de significación histórica. Así nos centraremos en una determinada formación social y en las relaciones económicas, sociales, políticas e ideológicas que se presentan históricamente en consonancia con el modo de producción dominante, el asiático y con otras relaciones típicas de otros modos de producción.

Encarar esta tarea de indagación no es sencillo porque Marx no publica su teoría sobre el modo de producción asiático en un lugar, ni le da una forma definitiva (Krader, 1975: xii; Bailey y Llobera, 1981: 23). ${ }^{3}$ De hecho, la única mención textual al modo de producción asiático ${ }^{4}$ la hace en el prefacio a la Crítica de la Economía Política y las formulaciones asociadas al mismo las hace en las Formen, una sección del manuscrito que fue elaborado por Marx entre 1857-1858 justamente como preparación de El Capital y Crítica de la Economía Política. Ello condujo a que a menudo la controversia se reduzca a la definición y caracterización de los supuestos atributos de tal modo de producción como podrían ser el despotismo asiático, la existencia de comunidades aldeanas autosuficientes y la ausencia de propiedad privada, aunque también a un cierto determinismo geográfico asociado al control de la irrigación. ${ }^{5}$ Además se ha recurrido a historizar ciertos conceptos y a rastrear su origen en una búsqueda de reconstrucción de los mismos. Incluso, se pondera que si bien Marx y Engels le dieron una nueva perspectiva, tal concepto no sería una idea absolutamente original de los autores alemanes. ${ }^{6}$ Sin embargo, debería entonces comprenderse en una tradición occidental pero con la originalidad de poder explicar la transformación de las relaciones sociales que corresponden a fuerzas productivas (Godelier, 1977: 33).

Otra dificultad radica en que estudiar el modo de producción asiático es pretender hacer levantar a un muerto, ${ }^{7}$ dado que la noción de modo de producción asiático fue negada, declarada antimarxista y expulsada oficialmente en la década del '30 (Godelier, 1977: 9). ${ }^{8}$ Luego fue mal recogida por Wittfogel en su monumental Despotismo Oriental. Estudio comparativo del poder totalitario $(1957)^{9}$ para enfatizar la característica hidráulica de las sociedades donde nace el modo de producción asiático ${ }^{10}$ y considerar que cuando existe en sociedades no hidráulicas, debe haber sido copiado o impuesto por una sociedad hidráulica (véase Godelier, 1977: 148). La crítica de Wittfogel era a la propia historiografía marxista y en cierta medida al concepto de modo de producción, pero más que nada era una crítica al sistema soviético (véase Sofri, 1969: 133-147, esp. 135). Wittfogel se había quedado con la determinación geográfica, enfatizado los aspectos 
político-administrativos y había eliminado los fenómenos socio-económicos sólo abordados a partir de una descripción fragmentada. El problema fue que a partir de las ideas de una sociedad hidráulica se transmitió un concepto de modo de producción asiático burdo y simplificado (Zamora, 1997: 17). ${ }^{11}$

En la URSS, Struve (1965), un académico alejado de las escuelas tradicionales europeas, niega la existencia del modo de producción asiático pero propone la existencia de una explotación dual en relación a dos grupos sociales diferentes: población agrícola y esclavos explotados, a partir de evidencia empírica y de pasajes de Richard Jones y del tomo 1 de El Capital (véase Mandel, 1971: 120). La discusión sobre un orden social esclavista en sociedades antiguas fue central en la historiografía soviética aunque a fines de los '40 en la Revista de historia antigua -Vestnik drevnei istorii- se consideraba ya a los campesinos como la masa de la población trabajadora en el Cercano Oriente. Estas últimas publicaciones fueron escritas bajo la influencia de las Formen que ya estaban disponibles en la Unión Soviética (Dunn, 1982: 66). ${ }^{12}$

Más tarde, Hindess y Hirst (1975: 3) intentan probar que no puede existir el concepto de modo de producción asiático entre la teoría marxista de los modos de producción. Aclaran enfáticamente que se trata de una noción teórica y debe ser construida a partir de conceptos marxistas generales (fuerzas y relaciones de producción, etc.) y no en base a los escritos de Marx sobre Asia; es decir a partir de El Capital en lugar de tener en cuenta los artículos periodísticos o las cartas sobre Asia. Asumen (1975: 180-181) que la forma básica de la renta precapitalista es la renta feudal como renta en trabajo, renta en especie y renta en dinero, cuestionando el postulado de Marx sobre la coexistencia de renta e impuesto en estados asiáticos, cuestión que retomaremos más adelante.

Anderson (1998 [1974]: 503) por su parte encuentra confusiones teóricas y metodológicas en la comprensión del modo de producción asiático. En particular la noción de aldea autosuficiente con su propiedad comunal es señalada por este autor como el principal defecto empírico de la construcción de Marx. Los elementos fundamentales de la aldea autosuficiente son el aislamiento y distancia respecto de los asuntos de estado. Anderson supone además que la presencia de un estado poderoso y centralizado presupone una estratificación de clase muy desarrollada, mientras que el predominio de la propiedad aldeana comunal implica una estructura social prácticamente pre-clasista o sin clases. Anderson insiste en que es incompatible en la práctica la autonomía y autosuficiencia de las comunidades de aldea y la importancia de las obras públicas de regadío a cargo del estado. La combinación de un estado fuerte y despótico con unas comunas aldeanas igualitarias es para Anderson intrínsecamente improbable.

Wickham (1994b [1985]: 49) ha cuestionado el modo asiático, afirmando directamente que no tiene validez analítica alguna. Es muy raro encontrar aldeas autárquicas junto a un estado que cobra impuestos y posee toda la propiedad de la tierra y que lleva adelante trabajos públicos a gran escala. Del mismo modo, Wickham considera que es demasiado específico política y legalmente. Así el feudalismo alcanzaría también a Oriente ya que toda sociedad de clase ha experimentado alguna forma de propiedad de la tierra y extracción coercitiva de la renta. ${ }^{13}$
11. O’Leary (1989: 141) explica que sobre todo los marxistas ortodoxos acordaban con Wittfogel en algunas cuestiones.

12. El título del libro de Dunn (1982) casi coincide con el título del capítulo 9 del ya mencionado libro Despotismo Oriental de Wittfogel: "El ascenso y la caída de la teoría del modo de producción asiático”.

13. La tributación por parte de un estado en Asia habría coexistido con relaciones feudales más típicas, aquellas de los propietarios de tierras que extraen renta de sus arrendatarios, y siempre estaría explícitamente en una relación antagónica con tal extracción de renta. 
14. Se distingue él mismo de Haldon señalando que este último considera la distinción entre impuesto y renta como puramente formal ya que ambos son modos de apropiación del excedente, y en este sentido variantes de un modo común de producción: el tributario. (continúa en página 108)

15. Publicado por primera vez en 1936 con el título Man makes

himself. Bartra (1975: 23) considera que Wittfogel copia de Childe la descripción del proceso de emergencia de los núcleos de las sociedades hidraúlicas.

16. Blackledge (2006: 101) toma como referencia también Qué sucedió en la historia (Childe, 1942) donde Childe desarrolla las contradicciones estructurales de los estados asiáticos en un intento de explicar el nacimiento y la caída del modo de producción esclavista asociado a estados tales como Atenas y Roma. Este autor (2006: 97-103) lo considera un referente en relación al modo asiático cuando plantea un análisis de los modos de producción y las transiciones sociales.

17. Plantea Godelier que Marx y Engels retomaron una hipótesis general según la cual la historia de

la humanidad es la transición de la organización social sin clases a las sociedades de clase. Toma la carta de Marx a Wydemeyer de 5 de marzo de 1852 (Marx, 1983 [1853]: 58). Sigue también esta idea Bartra (1975: 87-88, 110-112).

18. Según Zamora (1997: 12-13) es probable que Marx hasta le haya

dado al modo de producción asiático una cierta ubicación histórica: en el Cercano Oriente asiático con las primeras ciudades, obras hidráulicas comunitarias,

los primeros templos y palacios. $\mathrm{Si}$ bien ello es probable en relación al Egipto faraónico quedarían excluidas India y China que aunque estarían entre las primeras civilizaciones a orillas de los ríos, estarían en el Asia más lejana. 19. De acuerdo a las Formen, a partir de este sistema comunal primitivo se presentan vías alternativas de desarrollo: la oriental, la antigua, la germánica y la eslava. Amplía así las formas de sociedades de clase: esclavista antigua, feudal y burguesa, limitada a Europa occidental y central, contenidas en La ideología

alema y el Manifiesto comunista

(Hobsbawm, 1984 [1965]: 32). 20. De acuerdo a Krader (1975: 9) esta sería una de las direcciones a las que conduce la teoría del modo de producción asiático: la transición "de la economía primitiva a la economía política y de la sociedad primitiva a la sociedad política".
También Dunn (1982: 85-86) parece decir que la hipótesis del modo de producción asiático fue abandonada por el maduro Marx y no debe ser tenida en cuenta como "miembro completo" de la secuencia de los órdenes sociales. Asimismo que cualquier reposición del concepto del modo asiático dependerá de datos y consideraciones no avaladas por los propios Marx y Engels. Aunque este autor se sitúa él mismo como neo-asiático, avalando un estadio pre-feudal en lugar de un orden social esclavista.

Por su parte, Banaji (2011: 17-19) considera que el modelo bipolar de comunidades de aldea aisladas y un estado poderoso falla por tres razones: 1) la autosuficiencia de las aldeas es un mito (refiere solo a la India); 2) la idea de que el soberano asiático no se enfrenta a propietarios de la tierra poderosos y se carece de algún tipo significativo de formación de clase no es correcta a pesar de que fue seguida por Richard Jones y sugerida por Marx; 3) sobre la cuestión de la ausencia de propiedad privada de la tierra se basa en la repetición de la doctrina central de la tradición oriental sin ningún tipo de análisis más profundo. De todos modos Banaji (2011:22) propone caracterizar a los regímenes de Asia bajo el modo de producción tributario ${ }^{14}$ más que el feudal aunque diferenciando impuesto de renta y el feudalismo europeo de los sistemas asiáticos.

Hasta aquí las posiciones anti modo de producción asiático oscilan entre la invalidez de tal concepto desde su formulación hasta que dejó de formar parte del pensamiento de Marx y Engels en sus tardíos escritos. Incluso, para algunos marxistas, el modo de producción asiático no fue más que un despliegue de la arrogancia eurocéntrica de parte de Marx y Engels, un error teóricometodológico basado en una incorrecta interpretación de la historia de Asia, que luego fue abandonado por los autores (Tan, 2000: 1).

Una de las excepciones entre las décadas del ' 40 y' 50 cuando ni se mencionaba el modo asiático de producción fue la obra de Gordon Childe (véase Harris, 1994: 31-32). Es destacable sobre todo su publicación Los orígenes de la civilización (1954) donde rescata algunas de las tesis del modo de producción asiático, como el paso de comunidades de simples agricultores a estados que comprenden profesiones y clases. ${ }^{15}$ De acuerdo a Blackledge despliega el concepto de modo de producción asiático, contrariamente a la tendencia imperante desde su prohibición. ${ }^{16}$

Quien comprendió que se trataba de un modo de producción que se encontraba en el paso de una sociedad sin clases a una sociedad de clases fue Godelier (1971: 7). ${ }^{17}$ Reconoce la unidad de elementos contradictorios en la explotación de una minoría, la comunidad superior sobre las comunidades particulares, exhibiendo una forma última de sociedad sin clases -comunidades aldeanas-y una primera forma de sociedades de clase.

Podemos ver ciertamente al estado egipcio antiguo como un estado prístino ${ }^{18}$ porque se sitúa principalmente en sus comienzos nacido de la transición de una sociedad sin clases, mal llamada primitiva, en la que la extracción del excedente no es sistemática o está ausente y en la que priman las formas familiares y comunales de organización, ${ }^{19}$ a una sociedad política. ${ }^{20} \mathrm{El}$ problema de tal transición ha sido abordado en pos de entender cómo el estado asume 
determinados controles, en particular el de la propiedad de la tierra ${ }^{21}$ y cómo los proto-estados del Alto Egipto a partir de la conquista y de sus bases míticas extienden su dominio sobre el largo territorio egipcio.

Justamente Godelier (1971: 43) lo hace extensivo a Egipto, en el valle del Nilo, a fines del IV milenio aunque también a distintas épocas y sociedades de Europa (realezas creto-micénicas o etruscas), de África negra (reinos de Mali, Ghana, realeza de Bamún de Camerún) y de América precolombina (centroamericanas y andinas). En efecto, a partir de la década del '60, desde el énfasis de las Formen, se retomó en Occidente el concepto de modo de producción asiático en estudios sobre América precolombina, África negra, China, y por este motivo se propusieron otras denominaciones como modo comunitario-explotador o despótico de aldea (Chesneaux, 1964: 33-55). ${ }^{22}$

Así en la década del '60 se vuelve a escribir sobre el modo de producción asiático, se reanuda el debate entre marxistas en Inglaterra y Francia y también en la URSS. Hobsbawm (1965) realiza la introducción a la primera edición inglesa de las Formen y, al mismo tiempo, George Lichtheim (1963) publica un artículo analítico sobre el modo de producción asiático, realizando un agudo recorrido por los supuestos cambios de Marx respecto del modo de producción asiático. En la sección de estudios asiáticos y africanos del Centre d'etudes et de recherches marxistes ${ }^{23}$ y en La Pensée se publican distintos artículos y libros sobre el tema.

Los argumentos de Samir Amin merecen unos párrafos aparte porque refiere, aunque breve, directamente a Egipto ${ }^{24}$ siguiendo a Marx en sus consideraciones sobre la centralización estatal impuesta por razones naturales, ecológicas y las grandes obras hidráulicas y sobre la extracción de excedente al pueblo campesino. ${ }^{25}$ Incluso, señala la pervivencia de la relativa autonomía de la comunidad aldeana y de pequeñas familias. Pensando en los cuatro valles fluviales: Egipto, Mesopotamia, el valle del Indo y el valle del río Amarillo asume que el riego permite una productividad y una densidad poblacional mayor, lo que da por resultado formas de civilizaciones idénticas. La forma tributaria, esa clase-estado-teocrática-burocrática sobresale de las comunidades y se impone como organizadora. Hasta aquí no se encuentran diferencias excepto porque la llama formación tributaria.

Además Amin (1976: 53), agrega a estas explicaciones una interesante nota acerca del rápido debilitamiento de la comunidad aldeana y su casi desaparición, cuestión posible que también plantea Marx en las Formen, ${ }^{26}$ no obstante ésta subsistiría como comunidad de familias, pero perdiendo la propiedad jurídica del suelo en beneficio de la comunidad superior, cuando el estado se vuelve más poderoso. Por añadidura discute los términos del despotismo de la clase-estado porque "tiene en cuenta el interés común y organiza grandes obras útiles" (Amin, 1976: 19-20, 23). ${ }^{27}$ Llama la atención esta mirada benevolente que tiene Amin sobre la clase dominante en especial con respecto al campesinado. Es más, sostiene que la sociedad es despótica respecto a sectores como el artesanado libre, el comercio lejano pero "no respecto de los campesinos". El despotismo sólo es reconocible cuando una fuerza externa (el invasor bárbaro) se apropia del estado o "cuando el estado desaparece en beneficio de autonomías feudales que entonces las hacen semejantes a la Europa feudal" (Amin, 1976: 53).
21. Como plantea Wickham (1994: 62) es difícil saber cómo el estado llegó a asumir el control de toda la tierra, pero ciertamente se relaciona con las circunstancias de la conquista.

22. Zamora (1997: 31-32) llama a esta vuelta neo-modo asiático. También Dunn (1982: 103) denomina así a los argumentos antiesclavistas.

23. Por ejemplo Suret-Canale (1961: 101) postula que es posible encontrar semejanzas entre el modo de producción asiático y el modo de producción preponderante en África. Véase también Suret-Canale (1964). El húngaro Tokei pronuncia en Junio de 1962 una conferencia sobre el modo de producción asiático en el Centre d'etudes et de recherches marxistes de París. 24. En buena medida, lo equipara a China (Amin, 1976: 20-21, 24 y 27). 25. Para un análisis pormenorizado sobre Amin en relación a Egipto véase Campagno (2003).

26. Por ejemplo: “La producción misma, el progreso de la población (también ésta pertenece a la producción) suprimen necesariamente poco a poco estas condiciones; las destruyen en lugar de reproducirlas, etc., y con ello desaparece la comunidad con las relaciones de propiedad, sobre las que aquélla se basaba. La más tenaz y la que se conserva por más tiempo es necesariamente la forma asiática (...)" (Marx, 1984 [1965]: 101).

27. Parece tener la idea de una clase dominante en relación al estado. 
28. Publicada en 1974. Diakonoff empieza un poco antes por echar por tierra los argumentos del orden social esclavista predominantes en los estudios sobre las sociedades antiguas en Rusia, aunque como señala Dunn (1982: 75) al considerar que la tributación no constituye explotación su posición se aleja de los fundamentos del modo de producción asiático. 29. Sobre la influencia de Struve en Diakonoff véase Dunn (1982: 45-62).

30. Asimismo véase en Zamora en detalle los postulados de la escuela de Leningrado y las ideas de otros investigadores sobre las sociedades orientales y el modo de producción asiático en la URSS después de 1930.

31. Es injusto no detenerse en las publicaciones de orientalistas como Zaccagnini (1989); o las publicaciones de los encuentros de la Sociedad Jean Bodin, pero ello constituiría un trabajo en sí mismo.

32. Anderson subraya que en las Formen aparece como elemento nuevo y decisivo la idea de que en Asia y en otras partes existió una propiedad comunal del suelo por aldeas autosuficientes, oculta por el velo oficial de la propiedad estatal de la tierra, lo que habría de designar Marx como modo de producción asiático un año después. Podemos coincidir con Anderson en que se convierte en un elemento decisivo, sin embargo, como veremos más adelante, Marx escribe en 1853 acerca del sistema de aldea. Según el mismo Anderson (1998 [1974]: 494) Marx no confirmó nunca esta "nueva concepción" en sus escritos terminados y publicados.
Se separa de Marx al señalar que la comunidad aldeana del Egipto antiguo no es mucho más constrictiva que las de Europa de la Edad Media. No obstante ello, más adelante dividirá éticamente entre los señores feudales que oprimen a sus campesinos sin control y el estado oriental benevolente con los campesinos. Es clara la posición de Amin sobre la excelencia de Egipto y China como modelos (formaciones tributarias acabadas) y el intento fallido de imitación por otras regiones (formaciones precapitalistas periféricas). La Europa feudal se encuentra en esta última variante, aunque esa falta de centralización liberará a sectores mercantiles y la extensión del comercio junto a la disgregación de las relaciones feudales dará lugar al capitalismo. En suma, la gran, rica, resistente y benevolente formación tributaria del Egipto antiguo no pudo haber generado un sistema tan perjudicial como el capitalismo.

En otro orden, un intento de reeditar la noción de modo de producción asiático en el campo de las investigaciones del Cercano Oriente se desarrolla evocando la articulación de dos modos de producción: el palatino (o del templo) y el aldeano. Este modelo bisectorial fue introducido previamente por el investigador ruso Diakonoff en la década del '50, aunque su publicación en Occidente fue posterior ${ }^{28}$ Diakonoff formaba parte de la llamada Escuela de Leningrado ${ }^{29}$ y junto a algunos de sus colegas enfatizaron tal bipartición basándose en los derechos de propiedad de la tierra y en un sentido legal de libertad (Zamora, 1997: 23). ${ }^{30}$ En los estudios de la antigüedad oriental ${ }^{31}$ Mario Liverani vuelve sobre el modelo bisectorial a partir de un trabajo publicado en 1976 y en sus posteriores trabajos confluyen distintas proposiciones historiográficas, lo que permite una mayor aceptación por los estudiosos del área.

En los estudios sobre el antiguo Egipto, un caso excepcional es el de Ciro Flamarion S. Cardoso, quien publica diversos trabajos sobre el modo de producción asiático (Cardoso, 1982: 14-25, 1986, 1988, caps. 1, 3 y vocabulario crítico, 1990). En ellos, Cardoso apela a las ideas de Marx y Engels y considera que aunque el concepto no puede ser comprendido en los términos en que fue pensado sigue siendo válido para explicar el funcionamiento de las sociedades antiguas y constituye "una de las formas pertinentes de interrogar a la historia de esas sociedades" (Cardoso, 1990: 13-14). Seguiremos a Cardoso en esta apreciación.

\section{II}

Comencemos entonces por considerar como válidos los términos en los que Marx desarrolla en las Formen la presencia de una unidad identificable con un estado y la pervivencia de formas comunales, ${ }^{32}$ entendiendo la relación de apropiación y explotación como primordial, sin perjuicio de formas intermedias, secundarias, subordinadas, subsidiarias y derivadas que puedan encontrarse en las sociedades con ese modo dominante.

Si observamos el funcionamiento del estado egipcio antiguo y su permanencia en la historia faraónica, las manifestaciones de la estatalidad se aprecian en los distintos ámbitos y es difícil vislumbrar aquellos espacios donde no estaba 
presente la marca estatal. De este modo, en los inicios de la historia faraónica esta unidad omnicomprensiva aparece, y nótese que es en apariencia, como propietario superior y efectivo ${ }^{33} \mathrm{y}$ se apropia del trabajo de aquellos individuos que poseen parcelas en las tierras de las comunidades de aldea. Este modo de producción dominante sería el que proporciona los lineamientos generales a la totalidad: el modo de producción asiático. La mayor parte del plustrabajo pertenece al estado y las elites gobernantes traducido en impuestos y corvea obligatoria o azofra. Esta sería la forma dominante en la que se articulan el poder de explotación y de dominación sobre el conjunto social y es lo que permite su reproducción.

En este modo, el estado es el primordial receptor del excedente de producción de los productores inmediatos: la renta de la tierra es recibida en forma de impuesto. ${ }^{34}$ De esta forma es el estado o las instituciones estatales quienes los enfrentan como terratenientes y en este sentido coinciden la renta y el impuesto (El Capital III: Marx, 1966 [1894]: 555-556). Hindess y Hirst (1975: 192) llaman a este modo de apropiación binomio impuesto/renta y consideran que corresponde a una división del trabajo entre productores y no productores, la ausencia de propiedad privada y de una clase gobernante no subsumida en el estado, aunque dudan de su existencia. Asimismo realizan una serie de deducciones de las relaciones que están contenidas en tal modo de apropiación, aunque se preguntan si estos elementos permiten una articulada combinación de relaciones y fuerzas de producción. Su respuesta es negativa. Ponen el acento en que tal modo de apropiación supone dos tipos distintos de fuerzas de producción, las implicadas en el cultivo campesino independiente y las implicadas en el cultivo comunal. Aquí estiman arbitraria tal articulación y suponen que no existieron tales fuerzas de producción que correspondan al binomio impuesto/ renta. Se aprecia el acento en demostrar la determinación de las fuerzas de producción y la insistencia en la negación de un modo de apropiación diferente de la forma general de toda tasación estatal. Tal negación deriva en consecuencia en que el binomio impuesto/renta no supone un modo explotativo de apropiación. Aquí conjugan con Anderson la imposibilidad de que un estado que imponga formas de producción no dé lugar a clases.

Vemos que la articulación cerrada propuesta por Hindess y Hirst (1975: 194196) los lleva a plantear equívocamente diferencias respecto de la división del trabajo y la cooperación entre los miembros de la comuna, así como la regulación de tareas a gran escala, cuestión que niegan a los agricultores independientes. Las formas de la propiedad comunal pueden diferir en su aparición histórica e incluso en su evolución, aunque no su contenido que sería la relación del cultivador, el productor directo, con la tierra (Krader, 1975: 127-128). En las Formen, justamente Marx distingue como una manera de propiedad comunal que los individuos trabajan independientemente con su familia en el lote asignado en tal tipo de propiedad. Y si bien destaca el carácter colectivo para sostenimiento de la entidad comunitaria, dependerá de la presión fiscal y el mayor o menor control de la burocracia estatal, pero también de las relaciones contradictorias en el seno de las comunidades. Inclusive, tardíamente (después de Morgan; Krader, 1972) ${ }^{35}$ señala el dualismo de ciertas comunidades, de la llamada comunidad rural, entre la propiedad común del suelo y su explotación parcelaria por familias individuales (véase Godelier, 1977: 87-88). En la Carta
33. Marx (1966 [1894]: 453): “El propietario puede ser un individuo representando a la comunidad, como en Asia, Egipto, etc."

34. Tal es así que en Egipto ramésida el término shemw designa la cosecha y el impuesto a la cosecha, e incluso es difícil distinguir entre los términos que refieren a la calidad de la tierra y los términos que refieren a los impuestos de la corona.

35. Marx realiza comentarios sobre el libro de Morgan (1877), a propósito de las comunidades de aldea integrando otros trabajos sobre la India y las primeras civilizaciones. Está presente por esos años la discusión sobre la pervivencia de esas comunas orientales en la Rusia zarista. Véase O'Leary (1989: 128-129). Aunque algunos autores, como Dunn (1982: 85-86), sostengan que Marx abandona la teoría del modo de producción asiático después de Morgan y de obtener mayor evidencia; otros como Melotti (1977: 11) sostienen que las mismas ideas siguen vigen tes en el volumen III de El Capital, publicado por Engels en 1894, después de la muerte de Marx. 
36. "Cuanto más los productos de la comuna asumieron la forma de la mercancía, es decir, cuanto menos fueron producidos para el uso propio de sus productores más con el propósito de intercam-

bio, más la original división del trabajo primitiva fue sustituida por el intercambio también dentro del comuna (continúa en página 108)

37. En general la concepción del despotismo oriental no difiere de los argumentos previos de Marx aunque está interesado en poder explicar su evolución por ejemplo hacia formas de producción a partir de trabajo esclavo (Engels, 1987 [1878]: 168).

38. Hoffman (1979: 17) caracteriza al Egipto de los faraones como "sociedad de base aldeana". Cardoso (1986: 16 nn. 17 y 25-26) además de tomar esta idea de Hoffman, subraya los principios de la "organización aldeana comunitaria". (continúa en página 108)

39. Autores como Menu y Harari (1974: 125) plantean la organización administrativa centralizada bajo una realeza única en función de dos fuerzas: el dirigismo económico y la persistencia de estructuras comunitarias. (continúa en página 108)

40. Cardoso (1986: 10) previene sobre la consideración de algunos autores de un 'desequilibro real' y plantea comprender que trata efectivamente de un 'desequilibrio documental'. 41. Por ejemplo en el papiro Berlín 10470 de la dinastía XII-XIII donde se registra una esclava como propiedad compartida por

la aldea (Smither, 1948: 31-34). 42. La forma de organización del trabajo en phyles registrada en el Reino Antiguo y en el Reino Medio que consistía en la división en grupos cada uno con un nombre totémico, parece conservar antiguas formas previas de

organización (Roth, 1991: 142 ss.).

43. Cardoso (1986: 19) toma fuentes iconográficas y textos de la segunda mitad del tercer milenio para describir las aldeas y sus rasgos característicos.

44. Las divisiones artificiales entre

reinos e imperios proviene de la convención gestada en el siglo

XIX sobre la división de la historia faraónica en imperios/reinos a partir de Bunsen (continúa en página 109)

45. Kemp (2018: 197 ss.) propone para algunos casos una interacción entre iniciativas reales con intereses de las comunidades locales. 46. A partir de Moreno García (2004b: 39; 1996: 161-165).

Texto en la tumba de Herkhuf en Qubbet el-Hawa (Strudwick, 2005: 333; Urk. I, 131: 4-7). respuesta a Zásulich de 1881 cuando expone las posibilidades y condiciones de las comunas rusas, remite a la decadencia de las comunidades primitivas y a los distintos tipos de comunidades primitivas: todas basadas en los vínculos parentales naturales de sus miembros, luego puede existir posesión individual de parcelas, y por último "aunque la tierra de labor siga siendo propiedad comunal, se redistribuye periódicamente entre los miembros de la comunidad agrícola, de modo que cada agricultor cultiva por su cuenta los campos que se le asignan y se apropia individualmente los frutos de ese cultivo, mientras que en las comunidades más arcaicas la producción se practica en común y se reparte sólo el producto" (Marx, 1989 [1881]: 346). Este tipo primitivo de la producción cooperativa o colectiva y la producción parcelaria son las expresiones contradictorias del desarrollo de esas comunidades agrícolas. También Engels en el Anti-Dühring está interesado en el problema del origen de las clases y del estado en la comunidad primitiva ${ }^{36}$ y refiere de manera escueta a la delegación de funciones en ciertos individuos que actúan bajo el control de la comunidad agrícola y en las transformaciones que dieron lugar a la aparición de clases. ${ }^{37}$

En gran medida en el Egipto antiguo la producción agrícola procede de la organización campesina y/o aldeana, ${ }^{38}$ la cual contenía también sus propias condiciones de reproducción, aunque intervenidas históricamente cada vez más por el estado. ${ }^{39}$ Esta intervención debe matizarse si tenemos en cuenta que era irregular y errática y las aldeas agrícolas se hallaban relativamente aisladas en su hinterland durante parte del año, sosteniendo una fuerte identidad local (Eyre, 2010: 291) y una economía autosuficiente (véase también Eyre, 1999: 36). Lamentablemente se desconoce casi todo de tales aldeas (Eyre, 1999: 35; Moreno García, 2001: 429) ${ }^{40}$ o de los campesinos a excepción de las relaciones que establecen con las instituciones estatales (incluidas las religiosas) las cuales exigen la entrega de parte de la producción y/o trabajo obligatorio. De todos modos, son reconocibles evidencias de formas conjuntas de trabajo, propiedades compartidas ${ }^{41}$ y regulación de la justicia en consejos locales; es decir modos de funcionamiento comunal o clánico ${ }^{42}$ que persisten alrededor del trabajo, la propiedad y la administración de normas y pautas. ${ }^{43}$

Más aún, teniendo en cuenta la importancia de los cultos funerarios y divinos en esa formación social puede interpretarse que el mantenimiento de los mismos durante el Reino Antiguo se efectuaba mediante la asignación de tierras y poblaciones de las aldeas que eran dedicadas a ese fin por parte de la corona. Parecería que, al menos en el Reino Antiguo (ca. 2686-2125 a.C.), ${ }^{44}$ la realeza controlaba centros de culto en distintas regiones y que los faraones intervenían en las actividades cúlticas (Moreno García, 2004b: 32-34) ${ }^{45}$ Esta acción se formalizaba mediante la proclamación de decretos reales. Por este medio podía asimismo otorgarse inmunidad a tierras dedicadas al culto funerario de determinados individuos, con el objetivo de dedicar plenamente los recursos allí obtenidos a la realización del culto. Esto implicaba que el estado renunciaba a la percepción de los impuestos debidos y al cumplimiento de las obligaciones personales por parte de la población afectada. Sin embargo, este tipo de exenciones podía revocarse e incluso los bienes depositados en los almacenes del templo podían ser utilizados por los funcionarios del rey en misión. ${ }^{46}$ 
Los decretos de Coptos ilustran sobre la fundación creada ${ }^{47}$ y sobre la exención establecida por el rey sobre la misma (en Strudwick, 2005: 112-13). Tales fundaciones dependían del per-shena $\left.\left(p r-\check{S}^{\top}\right)^{\top}\right),{ }^{48}$ un centro administrativo de los dominios reales, o de un establecimiento dependiente de ellos. ${ }^{49}$ De acuerdo con Moreno García (1994: 41), se trataría de un edificio relacionado con labores agrícolas, que reunía mano de obra (Moreno García, 1998; Allam, 2004) y medios de producción, y que estaba adscrito a templos o instalaciones agrícolas del estado. A través de estas medidas, el palacio aseguraba que las actividades económicas del templo no fueran afectadas. Así se observa que los templos locales en determinados nomos se convierten en centros de la agricultura institucional y por lo tanto de poder local. ${ }^{50}$

A partir de estos y otros decretos reales se conoce que los jefes de las aldeas estaban obligados a proporcionar trabajadores para el cultivo de las explotaciones agrícolas de la corona (Moreno García, 2004a: 17), la corvea obligatoria:

Tú harás el reparto de la tierra de este centro de trabajo (per-shena) junto al que está a cargo de los jefes de las aldeas ${ }^{51}$ y a los consejos locales ${ }^{52}$ de la tierra bajo corvea y de los trabajos-sened (Urk I, 294: 15-16).

La advertencia de un rey a su hijo para que tenga cuidado con los hombres influyentes en la aldea y su recomendación de encontrar un hombre entre la gente de la aldea que sea un líder que lo proteja y que gane su lealtad da cuenta de las relaciones más directas que podían gestarse entre la realeza y los jefes de las aldeas (Helck, 1977: 6). Aunque también da cuenta de las diferencias jerárquicas generadas al interior de la aldea, introducidas desde el exterior, así como hace evidente que la relación entre el faraón y los habitantes de las aldeas estaba mediada por estos jefes.

Del mismo modo los habitantes de las aldeas, de acuerdo a los papiros de Gebelein, estaban registrados en listados ${ }^{53}$ y podían ser convocados para realizar distintos trabajos para el faraón, ${ }^{54}$ tal como la construcción de un templo o un canal o formar parte del ejército o de una expedición a las minas (Posener-Krieger, 1975: 212; Parra Ortiz, 2011: 178). A su vez varias aldeas podían estar bajo el control de un alto funcionario como se destaca en una inscripción en la mastaba de Metjen de la Dinastía IV: "Y él fue promovido a gobernante de Per-desu y de las aldeas que estaban bajo su control". Es probable que las demandas de trabajo fueran impuestas a las comunidades más que a individuos aunque es más difícil de precisar si para los proyectos de la corona se establecieron reclutamientos regulares (Eyre, 2010: 302).

Probablemente no deba pensarse como una relación inmutable y armoniosa la establecida entre las instituciones estatales y las aldeas, incluso entre los distintos actores institucionales que estaban a cargo de la organización de la producción agrícola en sus distintas instancias. Tampoco puede suponerse una eficiencia centralizada permanente y de manera monolítica. Pero ¿puede dudarse que la relación de explotación fundamental la dirigió el estado y sus instituciones sobre las aldeas agrícolas?
47. Decreto de Coptos (Coptos G) establece la fundación de un dominio para el mantenimiento del culto de una estatua real. El daño sobre el papiro no permite asegurar si el decreto fue establecido por Pepi II durante la Dinastía VI o si refiere a uno de sus sucesores (Strudwick, 2005: 114-115; Urk. I: 288-295). 48. Wb. IV: 507-508. Faulkner (1991: 9o) lo traduce como "establecimiento de trabajo". Véase Papazian (2012: 58-100). 49. Por ejemplo el dominio (per-djet - pr-d $-\underline{-}$-) actuaba como tenencia subsidiaria. Papazian (1999). 5o. A partir de ello, se piensa en una evolución desde el per-shena $\left(p r-\varsigma^{c} n^{c}\right)$ del Reino Antiguo al per-sen ( $p r s n$ ) del Reino Nuevo, y en el mismo sentido una mayor organización de las actividades económicas primero por el palacio y después por los templos. También que la economía basada en el templo del Reino Nuevo puede haberse originado en el Reino Antiguo, "cuando el Gran Dominio del rey cede un control activo económico a favor de los templos". Papazian (1999).

51. El término heka ( $h k 3)$ puede referir a gobernadores o a hombres de rango, pero principalmente a jefes locales. Eyre (1999: 40), Faulkner (1991: 178). Para un análisis específico véase Piacentini (1994).

52. Djadjat ( $\left.d^{3} d 3 t\right)$ consejos locales designados como colectivo. El término ha sido traducido como "magistrados, asesores" (Faulkner, 1991: 319).

53. Posener-Krieger llama la atención sobre cerca de 300 nombres pero no es posible saber si se trataba de la totalidad de la población. Posener-Krieger (1975: 215); Eyre (1999: 36 n. 20). 54. La mayoría de los registrados son trabajadores agrícolas, aunque también se especifican ocupaciones como pastelero, cervecero, pastor, medidor de grano, sellador de los graneros, "nómadas", entre otros. Troy (2002 [1998]: 11). 
55. Durante la Dinastía IV la corona se propone la incorporación del Delta y más tarde de una región situada en el Egipto Medio (continúa en página 109)

56. Debemos a Moreno García (2004a: 17) el análisis. (continúa en página 109)

57. Eyre (1999: 35) señala que estas comunidades rurales creadas podían ser pobladas con prisioneros de guerra o grupos de inmigrantes y que como dominios proveían al rey y la administración real (continúa en página 109)

58. Godelier (1971: 45) plantea que la contradicción interna es la unidad de estructuras comunitarias y de estructuras de clase. 59. Sobre el término whyt véase Gardiner (1947: 205*); Wb. I: $346,258,5.6$

6o. Redford (1993: 8) establece que "wahyet 'clan, familia' fue aplicado a aquellos pequeños campamentos

de grupos (continúa en página 109)

61. En los textos de Execración whyt refiere a clanes o '3mw "asiáticos" de Biblos. Véase Helck (1971: 53). (continúa en página 109)

62. Loret descubre el texto y lo publica en 1901. Véase la interpretación de Moret (1901: 11-39); también en Gardiner (1905);

Gaballa (1977); Allam (1989).

63. La localización de la aldea de Neshi podría vincularla a una colonización militar interna en esa área de inicios del Reino Nuevo.

Eyre (2004: 161-162) plantea que en esa área se registran ciclos de colonización en distintos períodos de la historia faraónica. 64. Por ejemplo aldea de Sinuhé (Wilbour A 79, 17; 87, 31; 97, 32); aldea de Merek (Wilbour A

35, 23); aldea de los soldados (Wilbour A 35, 45, 36, 12); aldea de Tamariscos (Wilbour A 12, 12; 15, 40; 20, 28; B 15, 20. 21), etc. 65. Aldea de Iryt (Wilbour B 11, 27; 12, 33); aldea de Amenmose (Wilbour B 20, 16); aldea de Nesh (Wilbour B 9, 22.24).

66. Sobre la distribución de la población de acuerdo a las ocupaciones en las distintas

áreas de acuerdo al papiro véase O'Connor (1972: 692-695).

67. Sobre la complejidad del término nemehw Zingarelli (2010: 89-90; 2015).

68. Volveremos más adelante sobre ello cuando tratemos acerca

de la propiedad de los nemehw.

69. Tal responsabilidad fiscal

comunal, delegando responsa-

bilidades en magnates locales intermediarios, es presentada por Eyre (1999: 45) como un problema no fácil de visualizar. (continúa en página 109)
Podemos detenernos en el proceso histórico de esta formación económicosocial y advertiremos que la corona y los templos avanzan sobre la tierra de las aldeas, interviniendo en algunas zonas (especialmente en el Delta, también en Elefantina) sobre la organización del espacio agrícola. ${ }^{55}$ En efecto, durante el Reino Antiguo, como mencionábamos, se registra la creación de instalaciones agrícolas de la corona en el medio rural. ${ }^{56}$ Un cierto tipo de campos, los akhet, dedicados a la producción de cultivos de cereales estaban situados en el dominio de estas u otras instituciones como los templos y estaban asociados a impuestos y corvea obligatoria. Las formas estatales parecen extenderse sobre tierras yermas ${ }^{57}$ aunque también sobre antiguas formas comunitarias, dándose en esto último una supuesta contradicción interna (Zamora, 1997: 4). ${ }^{58}$ No obstante se presente como una contradicción interna, la unidad global en esas zonas ya no es sólo en apariencia propietaria de la tierra sino que ha pasado al dominio real, aunque las comunidades persistan dentro de éste.

Veamos este problema en el desarrollo histórico de las aldeas whyt. ${ }^{59}$ Éste es un tipo de aldea alejado del espacio institucional que hace referencia a la familia-clan ${ }^{60}$ durante el Reino Medio (ca. 2055-1650 a.C.). ${ }^{61}$ Más se conoce en el Reino Nuevo (ca. 1550-1069 a.C.), dado que es mencionado en una inscripción (de Mes $)^{62}$ que trata sobre una disputa de tierras en el sur de Menfis, aunque tal aldea recibe el nombre del primer propietario de las tierras. Así algunas de estas comunidades se reconocían por nombres propios y parecen haber sido habitadas por la familia y designadas de acuerdo al primero que recibió las parcelas. Tales prácticas se dieron en el contexto de un proceso de colonización en la zona de Fayum. ${ }^{63}$

Sin embargo, un documento fiscal del período ramésida (del reinado de Ramsés V; en Gardiner, 1941-1952; Menu, 1970; Katary, 1989; Janssen, 1986) registra casi treinta whyt (a partir de Gardiner, Wilbour, IV: 74-75), muchas de ellas también designadas con nombres propios o refiriendo a las ocupaciones de los habitantes. ${ }^{64}$ La evidencia permite inferir que se trataba de aldeas que se encontraban en dominios del templo o tierras de la corona. Algunas de ellas estaban localizadas en las tierras de la corona (tierras khato), que son mencionadas en el texto B del papiro Wilbour. ${ }^{65}$ La población de las aldeas ${ }^{66}$ podía estar obligada a trabajar estas tierras khato, tierras de la corona, y durante el Reino Nuevo se registra una situación atípica en la documentación relativa a los nemehw (Wente, 1990: 130-131), ${ }^{67}$ poseedores independientes asociados a las aldeas que pagan en oro una compensación al estado. ${ }^{6}$

Mientras que en el Reino Medio los whyt sólo se asocian a la aldea en su sentido clánico o familiar, luego o se encuentran en tierras colonizadas o bien en dominios del templo y/o de la corona. Puesto que en el Reino Nuevo, miles de dominios agrícolas y centros de culto-administrativos dependen de los templos más importantes como el de Amón en Karnak. Tanto sea como aldeas basadas en lazos familiares como aldeas situadas en dominios de las instituciones, la relación del estado con tales aldeas se registra a partir de la fiscalidad. ${ }^{69}$ Tal es así, que en períodos de crisis se comprueba una mejora en las condiciones de vida, como señala Moreno García (2004a: 44), lo que estaría vinculado a la desaparición fiscal de las burocracias palatinas y mayor libertad de los campesinos para organizar actividades productivas. 
Claro que deben considerarse, por ser Egipto un estado territorial, las relaciones entre la clase dominante central que gobierna en determinadas coyunturas históricas y las elites regionales y locales que disputan tal poder. La historia de la centralización y descentralización política estatal es un reflejo de tales luchas. Por otro lado, tal regionalización impone una compleja constelación de instituciones político-religiosas que dependen en mayor o menor medida del gobierno central. Si bien recientemente se ha discutido el papel de los templos y santuarios provinciales como representantes de la autoridad estatal (Moreno García, 2004b: 32 n. 6), es indiscutible la formación de élites regionales, sobre la base de las antiguas divisiones administrativas $\left(\right.$ los nomos) ${ }^{70}$ y en base a redes clientelares.

Por otra parte, en los inicios de la organización estatal, hasta la Dinastía V, se reconoce la intervención de la familia real detentando los más altos cargos, como por ejemplo el de visir (a partir de Baud, 1999: 170ss.; Lupo, 2011: 109122). La estrecha relación de los funcionarios con el soberano disminuye en la medida que aumenta el número de funcionarios y acceden a los cargos individuos no emparentados con la familia real. Los vínculos se estrechan a través de recompensas de distinto tenor, entre ellas el usufructo de tierra de la corona, que posteriormente podía revertir al rey (volveremos sobre ello más adelante).

Asimismo, todavía en las primeras dinastías otro mecanismo fue el casamiento de princesas con altos funcionarios, de manera de sostener a través del parentesco los más altos cargos de la administración (Parra Ortiz, 2011: 149). Los grandes centros de población, a menudo heredades reales ${ }^{71}$ (por eso Marx habla de campamentos del rey; carta de Marx a Engels, Londres, 2 de junio de 1853, Marx, 1983 [1853]: 330) se convirtieron en capitales de los nomos. ${ }^{72}$ Hacia fines del Reino Antiguo un gobernador podía controlar varios nomos y ser reconocido como un gran potentado, en el contexto de la aparición de potentados locales y jefes de tropas (Moreno García, 2011a: 188-189).

Sin embargo, el estado no desaparece, se fragmenta. Aún a nivel regional se mantiene la relación entre las aldeas y los nomarcas o jefes regionales. Los nomarcas, por ejemplo los tebanos en el llamado Primer Período Intermedio (ca. 2160-2055 a.C.), asumen los títulos de la realeza y el control de los templos locales. Ya a fines del Reino Antiguo las elites provinciales reproducen en el mismo estilo de la realeza estatuas, capillas o mastabas que se consagraban como espacios de culto y objeto de divinización (Moreno García, 2004b: 34-35; 2011a: 190). ${ }^{73}$ De algún modo, el correlato de este proceso histórico es identificable en el espacio funerario en la medida que primero los beneficios del culto funerario son recibidos por el rey, luego por los miembros de la familia real, los funcionarios y los sacerdotes en áreas separadas de las pirámides. Durante el Primer Período Intermedio, desaparece la pirámide individual y un grupo familiar perteneciente a la elite local podía enterrarse en mastabas (Seidlmayer, 1990: 403).

En las declaraciones retóricas de tales gobernantes se destaca su papel de protectores de la población, se jactan de haber aliviado los efectos de las hambrunas. El contenido ideológico de tales proclamaciones se liga a la acción individual y ya no a estar al servicio del rey. Esta legitimación hacia los que
70. Sobre las formas de disolución de los nomos y el reemplazo de nomarcas por alcaldes, véase (Franke, 1991).

71. Distintos tipos y jerarquías de asentamientos fundados por la corona se desarrollan a lo largo de la historia faraónica como las ciudades de pirámides o asociados a estas últimas. Se optó por no desarrollar el tema debido a su complejidad y que es subsidiario de nuestra argumentación. Véase Lupo (2007).

72. Nombre griego de los $s p 3 t$, divisiones administrativas, distritales. Sobre la importancia de las capitales de los nomos en particular durante el Reino Nuevo, véase O'Connor (1972: 687 ss.).

73. Véase por ejemplo Heqaib de Elefantina: Habachi (1985). 
74. La producción escrita refiere al desorden político y social aunque expresando la necesidad de la realeza y de ciertos valores asociados a tal institución. Esta supuesta contradicción, dado que rey es sinónimo de orden, presente en los relatos literarios reviste a la ficción de argumentos políticos. Zingarelli (2010: esp. 211-215).

75. Por mencionar sólo algunos se establece un contraste entre los pequeños (nedyes) y los grandes (wrw).

76. En particular véase Wilson (1951: 123-124); Hayes (1961: 45).

Previamente también Erman (1894: 101); Hall (1924: 318).

77. La noción de clase media está asociada a procesos universales y a modernización, democracia, burguesía y liberalismo, como una clase en ascenso. Visacovsky y Garguin (2009: 13, 21-22). Este abordaje plantea problemas interpretativos documentales y cuestiones de índole metodológica que se anclan en discusiones historiográficas más amplias que atañen al mundo moderno. dependen de él introduce un nuevo tipo social en la retórica de las inscripciones, el de patrón, aquel que puede cambiar el destino y salvar de la desgracia a la población (Assmann, 2005 [1996]: 69, 118-132). La integración de las elites locales en los aparatos de estado y en la cultura y valores palatinos, aunque también a la inversa, se refleja en la inclusión de tales proclamaciones retóricas en la producción escrita del Reino Medio. ${ }^{74}$ Es en cierto modo acertada la apreciación de Assmann (2005 [1996]:146-149, esp. 148) respecto de la "retórica de los motivos", la inclusión de otras elites letradas a las que era necesario explicar y fundamentar los actos de la clase dominante y política gobernante.

Con todo, durante el Reino Medio se mantiene y aun se amplía y especifica la estructura burocrática sobre la base del sistema fiscal fundado en cálculos sobre la producción de la tierra y los canales (Callender, 2007 [2000]: 228). De igual forma, se sostiene un sistema de trabajo obligatorio que organizaba el propio estado pero existía una mediación con los jefes y representantes de las aldeas y ciudades. Se castigaba con severidad a quienes no cumplían con tales deberes e incluso a aquellos involucrados en la huida, conociéndose que eran enviados a fortalezas fronterizas como la de Askut en Nubia (Callender, 2007 [2000]: 228).

En concordancia con esta mayor burocratización se hace más visible el gobierno central en las distintas regiones y aumentan las obligaciones para con éste. Paradójicamente se delega parte del control local en los jefes de aldeas y ciudades. Templos y fundaciones piadosas asumen el cobro de grano por persona por cada parcela en su distrito y a su vez entregan impuestos a la corona, aunque ciertas instituciones podían ser eximidas de ese pago.

A pesar de ello, se destacan iniciativas y prácticas económicas (Diego Espinel, 2011:232) por sus propios protagonistas en especies de autobiografías privadas pero al mismo tiempo estos personajes portan títulos asociados a alguna institución religiosa, por ejemplo el sacerdote Mentuhotep (en Petrie, 1925: pl. XXIII; Lichtheim, 1988: 69). Se amplía el espectro social al que refieren los textos ficcionales y no ficcionales, ${ }^{75}$ dando lugar a una visión esquemática y taxonómica de la sociedad diferenciada. Autores de mediados del siglo pasado ${ }^{76}$ interpretaron este fenómeno como sinónimo de una Edad democrática caracterizada por la emergencia de una clase media compuesta de artesanos, comerciantes, entre otros. Más adelante se ha planteado incluso la aparición de un tipo de "burguesía" en la sociedad del Reino Medio (Loprieno, 1988: 87). La aparición de tal clase media a inicios del Reino Medio se fundamentó en evidencia funeraria y considerando otras referencias textuales e iconográficas (Richards, 2005). El ajuar de las necrópolis de esta época revela un elevado grado de riqueza en las tumbas de individuos que no pertenecían a la administración faraónica y otras tumbas secundarias atestiguando la existencia de redes de clientelismo en torno a magnates locales.

Los conceptos de clase media o burguesía son anacrónicos ${ }^{77}$ pero cabe plantear el interrogante acerca de los alcances de la diferenciación social en este período. La incorporación de categorías sociales que difícilmente se contengan en la población de las aldeas o en la alta elite o alta burocracia estatal es comprensible en una sociedad que comienza a ser medianamente compleja. Aceptamos que la evidencia es ambigua y en general la conciencia visible de sectores 
intermedios en los textos culturales parece haber estado en manos de elite letrada o sub-elite que los nombra y estima en términos de su propia existencia (evidencia de una "sub-élite"; Parkinson, 2002: 64-65; Richards, 2005: 15). Ello no niega la identidad de clase establecida por la explotación del trabajo, ${ }^{78}$ y el estatus que opera invariablemente como categoría en las sociedades precapitalistas.

Ya hemos mencionado que diversos autores como Anderson (1998 [1974]: 506), Hindess y Hirst (1975: 198) ${ }^{79}$ plantean de manera tajante que es inaceptable el modo de producción asiático dada la imposibilidad de existencia del estado sin clases. No obstante ello, es significativo el aporte de Hindess y Hirst (1975:198-199) respecto de que el estado y el nivel político desarrollan la contradicción entre la estructura económica y la superestructura ideológica en la transición de una sociedad sin clases a una sociedad de clases. Pero alejándose de tal contradicción, discuten los términos de la dominación de clase en el estado a través de la conquista y en particular que ninguna forma puede explicar la existencia de un estado que corresponda a la apropiación del excedente impuesto/renta.

La oposición binaria estado-comunidades es la forma en que se expresa el modo dominante de producción, solo que sería iluso negar la diferenciación y las intersecciones sociales en el marco de las aldeas, pero también en los dominios agrícolas de la corona y de los templos; así como las contradicciones entre e intra clases dominantes: familia real, miembros del palacio o nobleza de corte, miembros del templo, sacerdotes, funcionarios como escribas (De Melo Tunes, 1990: 61), militares, y entre familias provinciales.

En relación a ello, es atinada la sugerencia de Haldon respecto de la contradicción entre los intereses del "Estado" (el gobernante, la elite burocrática, la facción aristocrática dominante en la corte o en las provincias) y otras facciones de la clase dominante en relación al control sobre la apropiación del excedente y sobre su distribución. ${ }^{80}$ Sin embargo, estas contradicciones no inciden directamente en el modo de explotación del trabajo y sobre todo en las formas de propiedad, cuestión que abordaremos en el siguiente apartado.

\section{III}

En las cartas cruzadas, Engels (6 de junio de 1853) sostiene que la ausencia de propiedad de la tierra es la clave para la comprensión de todo Oriente (carta de Engels a Marx, Londres, 6 junio de 1853; Engels, 1983 [1853]: 335). Uno de los postulados de Marx es que no existe propiedad privada de la tierra, aunque sí reconoce la posesión y el uso privado de la tierra. ${ }^{81}$ Mucho después, en 1882, Engels sostiene en La época franca que la forma del poder del estado está condicionada por la forma de las comunidades y que entonces el modo de producción asiático aparece cuando las comunidades cultivan la tierra o la tierra es asignada a diferentes familias, no se ha constituido la propiedad privada y el poder del estado es despótico. ${ }^{82}$
78. Agradecemos a Carlos Astarita (comunicación personal).

79. Hindess y Hirst se basan en el irreconciliable antagonismo de clase que supone la existencia del estado de acuerdo a Lenin en $E I$ estado y la Revolución y a Engels en La familia, la propiedad y el estado.

8o. Haldon (1993: 146) lo plantea en relación a la autonomía de los estados tributarios.

81. Sofri (1969: 28) plantea que Marx no está libre de incertidumbres al proponerlo. También en Marx (1966 [1894]: 555) en El Capital, III: “(...) no hay propiedad privada de la tierra, aunque es común y privada la posesión y el uso de la tierra".

82. En 1884, cuando escribe El origen de la familia, la propiedad privada y el estado, Engels (1933 [1884]) se centra en la evolución occidental de las sociedades en particular porque liga la aparición del estado con la propiedad privada y la familia monogámica. Además, como él mismo dice, intenta verificar las hipótesis de Morgan en la prehistoria y en la historia antigua de Europa. Para otra explicación sobre el abandono de Engels véase Godelier (1971: 27-35). 
83. Marx (1984 [1965]: 69). También Marx (1966 [1894]: 555): "El estado es el Supremo Señor. Aquí la soberanía consiste en la propiedad de la tierra que se concentró en una escala nacional".

84. En la Sátira de los oficios, un texto literario del Reino Medio (Lichtheim, 1975: 184-193), que destaca las bondades de ser escriba frente a las dificultades de realizar cualquier otro oficio $y / o$ actividad, una apología de ser un funcionario escriba, se representan con exageración las adversidades del campesino en sus labores agrícolas y la acción del estado en manos del escriba y sus asistentes "con palos y garrotes" que llegan a buscar el grano. Se refleja la violencia institucionalizada hacia el campesino en primer lugar y luego hacia su familia. A pesar de la naturaleza sesgada del documento literario el cobro de la renta campesina por los funcionarios estatales parece instaurarse como mecanismo dominante. Versión del Reino Nuevo en Blackman y Peet (1925: 284-298); Lichtheim (1976: 168-175). Moreno García (2004a: 42 y 54) advierte sobre la complejidad de utilizar estas fuentes por su carácter retórico y didáctico y apela al uso de fuentes administrativas.
De modo más sutil en las Formen, Marx enfatiza que la unidad omnicomprensiva o superior aparece como el propietario superior o como el único propietario ("la unidad es el verdadero propietario") en la mayor parte de las formas fundamentales asiáticas. "La unidad superior está por encima de todas las pequeñas comunidades, se presente como el propietario único, y que, por lo tanto, las comunidades reales solo se presenten como poseedores hereditarios. Puesto que la unidad es el propietario auténtico y el auténtico presupuesto de la propiedad comunitaria, entonces esta misma unidad puede presentarse como un ente particular, que está por encima de las múltiples comunidades particulares, en las que el individuo en realidad está privado de propiedad; o la propiedad, es decir, la relación del individuo con las condiciones naturales del trabajo y de la reproducción, que se le presentan como cuerpo objetivo de su subjetividad, y que él encuentra ya dado como naturaleza inorgánica que le pertenece, aparece mediada para él a través de la concesión de la unidad superior -que es realizada en el déspota como en el padre de muchas comunidades-, al individuo mediante la comunidad particular". 83

La resolución empírica al problema de la propiedad de la tierra en términos del modo de producción asiático resultó en contrastar si en la documentación de una formación económico-social dada se registraban formas privadas de propiedad. La argumentación sobresimplificada "hay propiedad privada entonces no hay modo de producción asiático" recorrió publicaciones y discusiones sobre este modo, careciendo de complejidad categorial y de injerencia teórica.

Es posible afirmar que las relaciones y los medios de producción dominantes parecen corresponderse a formas políticas e institucionales y a formas de propiedad en un determinado modo de producción. En el modo asiático el plustrabajo es extraído en nombre del dios o del rey a los trabajadores de las comunidades o bien a los trabajadores en las tierras del estado. Estos rasgos, que pueden ser comunes a distintas formaciones sociales, se presentan en el Egipto antiguo desde los inicios del estado como los rasgos estructurales constitutivos.

¿Puede explicarse en el mismo modo de producción la extracción del plustrabajo en una unidad de producción basada en relaciones personales y la extracción del plustrabajo a comunidades o dominios funerarios, religiosos o de la corona?

Todo hace suponer que el carácter de la explotación y dependencia de los campesinos en el modo de producción asiático difiere de las formas de sumisión y explotación de los campesinos por ejemplo en el modo de producción feudal. Los agricultores egipcios podían poseer parcelas de tierra en las comunidades o incluso en las tierras dependientes de instituciones y debían tratar con funcionarios o intermediarios de su comunidad o aldea, en nombre del faraón. Estas relaciones eran impersonales, mediadas por la violencia a la hora del impuesto, ${ }^{84}$ por la cooperación o por la tributación a los dioses. Aun así, no se trata tan sólo del modo de apropiación (personal o impersonal) sino de la forma específica que asume la explotación en las distintas formas de propiedad y que evidentemente da lugar a prácticas sociales y económicas diferenciadas.

Pero volvamos en concreto al problema de la propiedad privada y la determinación mística de su ausencia/presencia en las llamadas sociedades asiáticas, 
en particular en el Egipto faraónico. Según entendemos, Marx propone en las Formen que no se desarrolla la propiedad privada en las llamadas sociedades orientales dado que el propietario de la tierra es el estado y las instituciones estatales y religiosas que forman parte de la por él llamada comunidad superior. En el Egipto faraónico se documentan tierras de las comunidades, tierras personales del faraón, tierras de la corona, tierras de fundaciones reales, tierras del tesoro u otras reparticiones del gobierno central y tierras de los templos, en una red compleja y yuxtapuesta de propiedades, con mayor o menor predominio de unas u otras según los períodos (Menu, 1982: 1). ${ }^{85}$

No obstante, la adquisición de campos "privados" se registra desde los primeros períodos de la historia faraónica aunque: 1) muchas veces yuxtapuesta a tierra de la corona, de los templos o fundaciones funerarias, y 2) en general como donación del rey o de la aldea/ciudad. Es innegable que ciertos individuos podían administrar ciertas propiedades y ello atestigua formas que conviven con el mecanismo extractivo dominante. Tal es así que en las transacciones de tierras (en el Reino Nuevo incluso a través de equivalentes) ${ }^{86}$ el valor de las parcelas es muy bajo, situación derivada del modo de producción dominante que sostiene la subsistencia directa.

Analicemos entonces las formas en que se presentan tales propiedades individuales y las relaciones de producción establecidas en torno a las mismas. Las tierras son cedidas a altos funcionarios como recompensa por sus funciones y podían tratarse de dominios para el culto funerario por una donación real.

Las tierras son concedidas por el propietario terrateniente (la corona) a una clase de señores no distinguibles del estado o de sus instituciones. Aquellos que poseen tierras son al mismo tiempo funcionarios estatales o dependientes de sus instituciones religiosas o funerarias. En otras palabras, durante el Reino Antiguo y el Reino Medio hay un supremo señor de la tierra, la soberanía de la tierra está concentrada a escala "nacional". En el Reino Nuevo, los grandes templos -en palabras de Kemp (1972: 676) adjuntos del estado-cumplen la misma función de supremos señores de la tierra.

Decíamos que un tipo de posesión de la tierra era la otorgada a funcionarios reales como remuneración por sus servicios. Este tipo de dominios se conoce por las autobiografías de los propios funcionarios que subrayan haber sido recompensados por el rey (Urk. I: 1 - 5; Goedicke, 1970: 5-20; Strudwick, 2005: 192-194). En la de Metjen, de la Dinastía IV, se dice que recibe de manos del rey campos de diversas dimensiones por sus actividades como gobernante de varios centros en el Bajo Egipto y por otro lado que hereda de su madre 50 aruras, además de adquirir tierras (200 aruras) con población del rey. En ese mismo documento la fundación de dominios a su cargo en particular de los nomos cuarto/quinto y segundo en el Bajo Egipto. Como sea, se transmiten, donan, heredan tierras relativas al culto funerario, creándose fundaciones destinadas a suministrar ofrendas y sostener el culto. ${ }^{87}$

Ante este tipo de evidencia, consideremos dos cuestiones relativas a la creación de dominios privados. La primera atañe a la heredabilidad de la tierra. Se advierte que en general ésta debía permanecer indivisa, sólo transmisible
85. La explicación de Menu respecto de la propiedad del faraón como el único que podía disponer sobre el suelo se apoya en el plano jurídico.

86. Transacciones de tierras con equivalentes, véase Baer (1962: 25-45); Zingarelli (2010: 94-96).

87. Otras muestras de donaciones: un tal Sabni de Elefantina (Dinastía VI) recibió un campo de once hectáreas después de cumplir una misión en Nubia (Urk. I: 140; Strudwick, 2005: 338); e lbi de Deir el-Gabrawi (Dinastía VI) recibió un campo de unas cincuenta hectáreas vinculados a un $h w t$ (Urk. I: 145; Strudwick, 2005: 364-365). 
88. Por ejemplo en Urk. I, 170-172; Strudwick (2005: 98-101)

89. Moreno García (2008: 108) señala justamente la ausencia de una verdadera aristocracia hereditaria territorial cuyos intereses pudieran entrar en conflicto con aquellos del estado. La nobleza es una nobleza de función, creada, mantenida y derribada por el estado sin que existan verdaderos contrapoderes entre el estado y las comunidades campesinas susceptibles de usurpar de manera durable ciertas funciones (fiscales, militares, ideológicas) soberanas.

90. Otras referencias en notas siguientes.

91. $h m-k 3$ "servidor del ka". Se denomina a sí mismo como $b 3 k$ $n \mathrm{pr} d t$, "servidor del dominio funerario" (Cardoso, 1993: 107). 92. Se encontró en una tumba de Meseh en la necrópolis tebana, una de las cuatro pequeñas tumbas en el extremo norte de Deir el

Bahari en Tebas (Winlock, 1922).

El propietario probablemente era un dependiente de Ipi, visir de Nebhepetre-Mentuhotep (Goedicke, 1984: 3). Quizás del visir en Tebas llamado Ipi (Diego Espinel, 2011: 231). Sin embargo, Goedicke (1984: 12) pone en duda que fuera $h m-k$ ' "servidor del ka" del culto funerario del visir Ipi ya que no lo explicita el propio documento. 93. Moreno García (2004a: 86 ss., 191-197) señala la importancia de la familia extensa en la organización social. Con diferente opinión Cardoso (2009: 90). 94. Recibiendo un modesto estipendio por sus servicios, el agricultor debería haber permanecido dependiente de su propia tierra y de la tierra que él administraba del culto funerario (Grajetzki, 2009:151; Allen, 2002: 105-106).

95. La metáfora del hambre está presente en las autobiografías contemporáneas a estos documentos. Véase, por ejemplo, la inscripción de Ankhtifi de Moalla. Vandier (1950); Lichtheim (1975: 3-12, 83, 8586); Serrano Delgado (1993: 85-89). 96. Véase por ejemplo el $d{ }^{3} d 3 t n t$ $p r d t$ "consejo que funcionaba tanto como una organización administrativa como un tribunal en las grandes áreas del Reino Antiguo" (Menu, 2004:180). de padres a hijos y de acuerdo a la información disponible no se podía ceder a un tercero, probablemente porque en esencia continuaban siendo propiedad del faraón. La segunda, en conexión con esto último, es que el rey adjudicaba las tierras por las funciones del individuo. ¿Revertían a la corona cuando otra persona sustituía en el cargo a la recompensada?

Cierta disposición en el Decreto de Neferirkara de la Dinastía V permite contestar parcialmente este interrogante:

(y con respecto a) algún noble, conocido del rey, o persona afectada a las ofrendas reversibles (28) que actúe contra este decreto de mi majestad (29a) que ha sido registrado en la Gran Residencia, (29b) (su) casa, tierra, gente, y todo lo que posea será quitado y será puesto a trabajar obligatoriamente. ${ }^{88}$

Si bien se trata de una norma real establece que los individuos que reciben propiedades no tienen soberanía. No hay grandes dominios que den lugar a la gran renta. La tendencia historiográfica es pensar en la gran concentración latifundista con aumento de relaciones de servidumbre vinculada a la propiedad feudal. En esta misma dirección, se tiende a confundir feudalismo con aristocracia; en Egipto es factible identificar esencialmente aristocracia estatal. ${ }^{89}$

La documentación epistolar relativa a Hekanakhte (James, 1962; Baer, 1963; Allen, 2002), ${ }^{90}$ un sacerdote funerario ${ }^{91}$ ligado a una fundación piadosa dedicada al culto de la estatua de un alto funcionario estatal ${ }^{92}$ y también cabeza de un grupo familiar extendido, ${ }^{93}$ plantea una serie de cuestiones en torno a la propiedad y el arrendamiento de los campos. Descrito como un hacendado por Wente (1990: 58); de acuerdo a Eyre (1999: 48-49) puede considerarse que pertenecía a una clase de notables intermediarios rurales visibles en la documentación a partir del primer período de fragmentación estatal. De algún modo, esta documentación provee información sobre la unidad doméstica y la familia extendida como la unidad básica de organización rural. Ciertamente, por un lado el centro de este sistema doméstico extendido referido en la documentación estaría en lo que Hekanakhte denomina "mi propiedad" con las tierras adjuntas trabajadas por él mismo, su familia y otros trabajadores. Otros campos dependientes eran arrendados a cultivadores a cambio de raciones mensuales en grano y ropa. Probablemente, estos campos los haya recibido como donación perpetua a cambio de sus funciones (Allen, 2002: 149, 178), ${ }^{94}$ Son llamativas las referencias a costos, reservas de semillas, la maximización de la cantidad de tierra cultivada, tejido doméstico y la ropa vendida, etc.

La relación de las propiedades mencionadas por Hekanakhte con la fundación en la que se desempeña como sacerdote no es evidente como tampoco si la renta obtenida de la producción permite algo más que la subsistencia de la familia y demás dependientes. Sí se mencionan, quizás exageradamente, situaciones de extrema pobreza; la familia y dependientes estarían hambrientos en un mal año. ${ }^{95}$ Ahora bien, estas "casas" de la pequeña elite estaban ligadas a las organizaciones estatales de algún modo que es difícil de definir. De hecho, este tipo de dominios funerarios $(p r-\underline{d} t)$ funcionaban como posesiones subsidiarias ${ }^{96}$ del per-shena centro administrativo, ya mencionado, de los dominios reales en períodos de centralización política. En las cartas de Hekanakhte en 
una ocasión se denomina a sí mismo como $b 3 k n ~ p r \underline{d} t$ "servidor del dominio funerario" ${ }^{97} \mathrm{y}$ en los documentos contables el per-shena aparece mencionado entre los lugares donde están disponibles los suministros.

Con todo, Hekanakhte aparece administrando sus dominios, estableciendo pautas, dando órdenes sobre el cuidado de las personas, del cultivo, entremezclándose relaciones parentales y económicas. En los cómputos figuran provisiones disponibles que se encuentran en distintas casas, aldeas y en el mismo per-shena. Es decir que estas formas de propiedad individual se podían yuxtaponer a la producción de las aldeas y las sociedades locales, ligando a las personas por lazos de dependencia y patronazgo (Eyre, 2010: 302).

Sin embargo, este tipo de propiedad individual no da lugar a una aristocracia terrateniente hereditaria, cuyos intereses, si pueden entrar en conflicto con la corona, están muy lejos de poder disputar la primacía al estado central. ${ }^{98}$ Es decir que la aparición de tal tipo de propiedad no transformó las formas dominantes de explotación sobre las comunidades y sobre los dominios de la corona. Incluso, para el Reino Nuevo los grandes templos tenían bajo su égida la mayor parte (2/3 parte) de las tierras de templos más pequeños, dominios funerarios y aldeas enteras de acuerdo a la documentación del período. En síntesis, los principales propietarios institucionales de tierras eran los templos, ${ }^{99}$ recibiendo ingresos del producto de los grandes dominios, rentas entregadas por arrendatarios de las tierras del templo y arriendo de servicios entre instituciones. Es evidente la relación entre la corona y las instituciones religiosas en el hecho que los dominios de estas últimas estaban a cargo de altos funcionarios, que eran frecuentemente dignatarios del palacio o funcionarios de la corona. Estos últimos a su vez podían ser propietarios de pequeños campos en las jurisdicciones de los templos o la corona.

Parcelas de igual tamaño (entre 3 y 5 aruras) podían estar asociadas a una entidad local y a categorías profesionales diferentes (soldados, jefes de caballerizas, mujeres) y las mismas tenían un carácter hereditario y en general inalienable. ${ }^{100}$ Sin embargo, podían ser sub-arrendadas. La división de la tierra y el impuesto a la cosecha estaban evidentemente muy vinculados. De acuerdo a Menu, basándose en Heródoto, tal división de la tierra y la adjudicación a particulares en tierras del templo fue obra de Ramsés II que instauró un sistema de recompensas a funcionarios, reemplazando otros sistemas previos. Documentación posterior refiere a los ingresos anuales recibidos por los templos tebanos, sus tesoros, almacenes y graneros. ${ }^{101}$

En suma, tierras de particulares se registran más conocidamente en este período a diferencia de los anteriores, siendo su origen la donación real o la herencia familiar. Consideremos en primer lugar los tipos de donación o transferencia real. La evidencia ceñida a las donaciones permite definir que altos funcionarios de la corona o militares eran recompensados con tierras desde la Dinastía XVIII. Debe tenerse en cuenta que los campos varían en tamaño y la región donde se hallan (Tebas, Nubia, Giza, Qantir y Menfis): es categorial la diferencia entre 154 aruras de tierra dadas a un funcionario de la corona (jefe del harén real) ${ }^{102}$ que además se explicita dependen de un templo en Giza, y 16 aruras de tierra en una aldea y un curso de agua cercano a Qantir dadas a un militar como recompensa (Estela Cairo JE 88879, del reinado de Ramsés III: Meeks, 1979: 664; Schulman, 1988: 22-24).
97. De acuerdo a Goedicke (1984: 81) $p r \underline{d} t$ no debe leerse referido al dominio así identificado, sino como pr "casa" "dominio" y $d t$ como "eternamente".

98. Véase Moreno García (2008: 108). No obstante, Moreno García encuentra problemático considerar al estado como una institución distante, sin influencia en cuestiones locales; él enfatiza un modelo que contiene en sí mismo la noción de descentralización, delegación de poder y clientelismo. En otras palabras, señala el riesgo de caer en lo que él considera la antigua tradición historiográfica que opone la fragilidad de las formaciones estatales orientales con la persistencia de las aldeas y el conservatismo rural. Para una lectura sobre cuestiones y posiciones historiográficas véase también Moreno García (2008: 99-106).

99. El papiro Harris y el ya mencionado papiro Wilbour ofrecen información sobre la administración de los templos y sus propiedades (Grandet, 1994).

100. Acerca de la prevalencia por zonas de las diferentes categorías, véase (O’Connor, 1972: 693-695).

101. El papiro Harris registra donaciones al templo de ca. 2680 km2 (Grandet, 1994: 91-101). Esto representaría más de la mitad de la tierra cultivable en el Alto Egipto (Eyre, 2010: 303). El Papiro Harris también registra donaciones de 3.000.00o khar de grano del templo de Karnak, y 309.950 khar a Medinet Habu y templos menores (Haring, 1997: 412-414). 102. Estela Cairo JE 28019 del reinado de Ay: Zivie (1976: 177-182, 273-274, pl. 13); Meeks (1979: 663). También Estela Berlín 14994, del reinado de Thutmosis I, registra 150 aruras dadas a un hombre del ejército llamado Nekry: Schulman (1964: 98, no. 8o); Meeks (1979: 661-662). 
103. Una inscripción en la tumba de Pennut en Aniba, fechada en el reinado de Ramsés VI (Steindorff, 1935: pl. 101) muestra regulaciones tomadas por ese faraón a favor de su propia estatua: Inscripción de la estela de Stuttgart (Menu, 1998: 140).

104. Estela de Israel, línea $16=$ Cairo 34025 vs.: Spiegelberg (1897:

1-25, pls. 13-14); Lacau (1926: 52-59, pls. 17-19); Kitchen, (1981: 12-19); Lichtheim (1976: 73-78).

105. Janssen (1986: 363) Ilama a esos pequeños propietarios: "propietarios virtuales" o "propietarios privados", cuyos derechos sobre la tierra pueden haber sido los mismos que los de los propietarios privados, aun cuando la tierra perteneciera teóricamente al faraón.

106. Testamento de Naunakhte (Papyrus AshmoleanMuseum 1945.97) de Ramsés V, Černy (1945: 29-53); Théodoridès (1966: 31-70); Allam (1973: 268-74, no. 262); Kitchen (1983: 236-240); Mc Dowell (1999: 38-40, no. 14). 107. myt-per literalmente "lo que está en la casa". "Ein Testament machen", Wb. I: 73; véase Seidl (1939: 58); Thédoridès (1970).

108. Durante el Reino Nuevo, existían consejos centrales (gran kenebet) cuyas funciones eran tanto judiciales como administrativas.
Este último tipo, de recompensas dadas a militares, se registra también en inscripciones autobiográficas (Urk. IV, 1-10; Loret, 1901; Lichtheim, 1976:12-15), donde el beneficiado subraya que "gente, ganado y campos" le fueron entregados en su propia aldea o ciudad. En el Egipto Medio se registran poseedores de tierras designados como militares en el papiro Wilbour (Katary, 1989: 69), aunque quizás deba vincularse al ya mencionado proceso de colonización en esa zona (Eyre, 2004: 161).

En general las donaciones se hacían a los dioses (Montu, Amón-Ra, Mnevis, Horakhty, Amón; una al templo de la esfinge en Guiza), o tierra podía ser donada por el rey para el culto de una estatua real. ${ }^{103}$ Un sacerdote podía ser el administrador teniendo la obligación de ofrecer un buey como ritual a la estatua cada año. El dominio se componía de una cantidad de aruras a cargo del propio sacerdote y el resto de los campos podían estar a cargo de diferentes personas que los administraban.

Mencionamos previamente a los poseedores independientes (nemehw) en las tierras de la corona (khato) que pagaban una compensación directamente al tesoro a finales del período ramésida. La conexión entre los poseedores independientes y las aldeas debe considerarse a la luz de que los habitantes de las aldeas eran forzados a trabajar en las tierras de la corona y se hace hincapié en la documentación que se los exime de tales tareas a cambio de un pago en oro. Pero además, la estela de Israel ${ }^{104}$ explícitamente señala un cierto contraste: "él (rey) ha permitido a los nemehw volver a las aldeas y él (rey) ha permitido a los funcionarios (srw) conservar sus posesiones" (véase Römer, 1994: 412-451).

Es decir que los nemehw parecen haber sido poseedores de pequeñas parcelas de tierras en el contexto de las aldeas y, de algún modo que la documentación no nos deja ver cómo, obtenían oro para el pago del impuesto y se eximían así de la corvea. Se los ha identificado con los poseedores de parcelas en el papiro Wilbour y en otros documentos del período (Gardiner, 1948: 206; Janssen, 1986: 363; Menu, 1970: 30), ${ }^{105}$ pero con la información disponible no parece posible documentar tal adscripción.

En segundo lugar, la herencia familiar se reconoce en documentos judiciales o testamentos, desconocidos en los períodos precedentes. Un testamento de una mujer que se llama a sí misma nemehyt "de la tierra del faraón" ${ }^{106}$ habilita a indicar que los campos de esta categoría de individuos podían ser transferi$\operatorname{dos}^{107}$ por herencia a los hijos. Este derecho de decidir sobre la propiedad heredada de su padre, de su primer marido y una parte de lo acumulado con su segundo esposo parece abonar la hipótesis de que la herencia quedaba dentro del núcleo familiar. A todo esto se trata de una familia de la elite vinculada a la necrópolis.

Es destacable que los consejos locales como el kenebet ${ }^{108}$ intervenían en este tipo de actos atendiendo cuestiones relativas a derechos y disputas sobre las propiedades, teniendo además funciones administrativas. Asimismo, aumentan el número de referencias en documentos escritos, registros de tierras y catastros, juicios personales y a menudo decisiones del oráculo respecto de procesos judiciales sobre campos. 
¿Este tipo de prácticas económico-sociales reforzaba la naturaleza privada de la propiedad? Entendemos que la naturaleza de la documentación debe ser analizada en pos de distinguir el tipo de propiedad y los aspectos involucrados en la transferencia. En general se revela un sistema familiar de tenencia y aunque no se establezca de forma explícita cómo las familias obtuvieron los campos uno puede inferir que se trata de favores o recompensas reales debido a los títulos de los hombres de la familia: un niñero del hijo real, en favor de su esposa y sus hijos, ${ }^{109} \mathrm{o}$ el escriba de la mesa de ofrendas que fue a la corte con documentos para probar sus derechos y los de sus hermanos sobre algunas aruras de tierra. ${ }^{110}$ Una cuestión que debe tenerse en cuenta es que tales campos podían estar integrados al sistema de tenencia de los templos y debía entregarse un pago a los rituales sacerdotales. En otro orden, ejemplos remiten a la práctica de la adopción de la esposa como hija o a la adopción de esclavos para mantener la propiedad en el seno de la familia. ${ }^{111}$

De acuerdo a esta evidencia, Eyre sostiene que se crean "ciertos tipos de propiedad de la tierra disponibles (por ejemplo privadas), como un mecanismo feudal vital". ${ }^{112}$ Este autor considera que "conlleva seguridad de tenencia, pero entonces aparecen complejas tensiones sociales sobre los derechos de propiedad". Los documentos nos permiten reconocer tensiones sociales resultando de derechos de propiedad de familias diferentes y sus descendientes. ${ }^{113}$

En resumidas cuentas, encontramos formas de propiedad individual, si se quiere privada, durante el Reino Nuevo, pero ésta no se desarrolla; no conduce esta forma de propiedad a formas propiamente feudales. La idea de Godelier (1971: 47) de que ciertas formas del modo de producción asiático podían conducir a ciertas formas de feudalismo no puede corroborarse en este proceso de transformación de las relaciones de propiedad en esta formación económico- social.

En otras palabras, no se reconoce una clase terrateniente monopolista, tampoco se reconocen grandes propietarios que tuvieran poderes coercitivos ni económicos para imponer su control, ni de modo informal, ni a través de la justicia pública o privada. Es decir, se advierte que se estaría en las antípodas de lo que implicaría el modo feudal de acuerdo a la enunciación de Hindess y Hirst (1975: 18-19) y del propio Wickham (1994a [1984]: 10). Aun cuando puedan hallarse formas de renta, éstas en su mayoría parecen encontrarse yuxtapuestas a las formas de propiedad estatal (o del templo) o a las formas de propiedad de las aldeas o ciudades. Es posible referir a formas de propiedad individual que entran en contradicción con las formas de propiedad dominantes durante el Reino Nuevo.

\section{IV}

Marx (1984 [1965]: 87) plantea en las Formen que las "ciudades en sentido estricto se constituyen junto a aquellas aldeas, que son puntos esencialmente favorables para el comercio exterior; o donde el jefe de estado y sus sátrapas cambian su renta (producto excedente) por trabajo, gastándola como fondo de trabajo". Se vuelve irrefutable esta tesis de Marx cuando nos hallamos ante la

109. En este caso se expresa de una manera monumental-sobre una estatua- por su vínculo con la realeza. $=$ Estela Cairo 34016 = Estela Cairo 34016: Urk. IV, 1065-1070; también Thédoridès (1970); Spalinger (1984: esp. 633). 110. Papiro Berlín 3047, año 46 de Ramsés II: Helck (1963: 65-73); Baer (1962: 36-39); Kitchen (1979: 803-806); Katary (1989: 223-225). 111. Papiro Ashmolean Museum 1945.96, conocido como el Papiro de Adopción: Gardiner (1940: 23-29); Théodoridès (1965: 79142); Allam (1973: 258-267, no. 261); Cruz-Uribe (1988); Allam (1990: 189-191); Eyre (1992).

112. Este tipo de propiedad de la tierra pudo haber sido parecida a la propiedad privada, resultando en ciertos tipos de disponibilidad de la tierra (Eyre, 1994: 112-113). 113. Ibid. 
114. Aunque puede haber excepciones como Abidos de acuerdo a Richards (2005: 174).

115. La aldea de los trabajadores. Set maat "Lugar de la verdad". contundente evidencia disponible en una formación social como la que estamos considerando. En particular, es lícito argumentar que la disponibilidad de excedentes y la acumulación que le permite a la clase de funcionarios obtener bienes, por ejemplo funerarios, más allá de los otorgados por el rey, surge de la propia esfera estatal y se hace evidente en los centros "metropolitanos" donde residía la elite. ${ }^{114}$ En la Tebas del Reino Nuevo por ejemplo son los artesanos de las necrópolis los que generan recursos y amplían la circulación de bienes pero están habilitados por su propia dependencia y por las raciones que obtienen del estado. Probablemente la propia posibilidad de acumulación económica y cierto prestigio provenga de su articulación con instituciones estatales. De esta manera se llega a la conclusión que el estado egipcio como un estado distributivo (entre la clase dominante y las altas clases de funcionarios) niega la acumulación de una elite de funcionarios y artesanos privilegiados pero al mismo tiempo la habilita como efecto secundario de su funcionamiento. Asimismo, entre los mecanismos de circulación intersticiales pueden reconocerse en este período por ejemplo comerciantes operando con excedentes derivados de las clases dominantes. Dicha acumulación privada en palabras de Marx (1984 [1965]: 103) se hallaría "en los poros del mundo antiguo".

Si analizamos la circulación de bienes funerarios en especial durante el Reino Nuevo se observa que la mayoría de los bienes y las posibilidades de enterramiento suntuario estaba en la órbita del estado, cuestión que reviste una cierta importancia por la cultura de la muerte desarrollada en el Egipto faraónico. No obstante ello, las demandas de las elites son reconocibles en los distintos períodos de la historia faraónica. Sin embargo, durante el Reino Nuevo la circulación de bienes y personas se acrecienta, generando en ciudades, como Tebas y en torno a Deir el-Medina, ${ }^{115}$ procesos de apropiación de la circulación e intercambios a partir de equivalentes en metales.

En la documentación del Reino Nuevo se vislumbran actores económicos como los mercaderes o shutyw que brindan alternativas diferentes al mecanismo dominante. Estas relaciones económico-sociales no siempre pueden ser incluidas en el circuito distributivo estatal. Tales mercaderes eran a menudo agentes del templo pero también podían depender de jefes de tropas, cantantes de Amón y otros funcionarios. Estas situaciones parecen haber sido funcionales a un sistema complejo de relaciones económicas en las que el estado monopolizaba los mecanismos de control pero éstos de ninguna manera eran unidireccionales.

¿Cómo puede explicarse la aparición de estas formas de circulación económica? Las respuestas en el campo egiptológico tienen sus raíces en el campo teórico: o en la antropología económica o en la teoría económica. En el primer caso entendiendo la economía egipcia como la otredad absoluta, en el segundo como una versión primitiva de la economía moderna. El principio de redistribución propuesto como mecanismo integrador por Karl Polanyi (1957: 250-256) fue el principio vertebrador con el que se comprendió a la economía egipcia faraónica. El problema es que tal principio reduce su alcance a la posibilidad de descripción de la economía aunque no a su comprensión analítica, confundiendo las formas de producción con las formas de circulación. De todos modos, su validez reside también en ello, ya que a partir de este principio se entiende que en las 
sociedades antiguas la economía aparece sometida a una unidad política y no a decisiones individuales atomizadas (Godelier, 1989: 224-225).

También explicaciones combinadas proponen que una vertiente institucional de tipo redistributivo debía satisfacer demanda individual, por ejemplo Barry Kemp en El Antiguo Egipto: Anatomía de una Civilización (2018: 296-307). Sin embargo, a nuestro entender, ese poder de la demanda privada, descansaría no en un poder "individual" sino en procesos de acumulación secundaria gestados por los propios excedentes estatales.

Respecto de cómo se gestan tales procesos, debemos explorar en la economía estatal, especialmente en los templos en el área tebana. Fuentes principales de recursos, es notable la producción de las tierras bajo su administración, así como el almacenamiento ${ }^{116}$ y el transporte. ${ }^{117}$ Ciertamente, como anunciábamos más arriba, el papel de los templos sin duda fue significativo respecto de la administración de la tierra y la recolección de impuestos. Por ejemplo los templos de la orilla occidental sabemos que eran responsables del pago de raciones a trabajadores diversos y a artesanos especializados. Documentos del período permiten observar cierta conflictividad entre sectores que se expresan como fenómeno histórico en el descontento por falta de pago de raciones. ${ }^{118}$ Es notable este procedimiento no usual que incluye demandas económicas y cuestionamiento del orden burocrático.

Paradójicamente, los artesanos además de subsistir con las raciones entregadas por los templos desarrollan prácticas pseudo-privadas en la esfera de la producción doméstica y artesana que se manifiestan en transacciones con animales productivos (bueyes), para transporte (burros) y con objetos funerarios (sarcófagos, estelas, estatuas), o de uso cotidiano (muebles) registradas en ostraca. ${ }^{119}$ Se reconoce en tales intercambios que miembros especializados de la aldea obtuvieron beneficios individuales de este intercambio. ${ }^{120}$ No se debe ello a la acción de los sujetos, ni a la sumatoria de las mismas sino a la lógica del funcionamiento social (Astarita, 2000: 22).

No obstante, uno no debe dejar de tener en cuenta que la base del excedente se hallaba en la provisión estatal de bienes. El crecimiento mercantil de Deir el-Medina se basa en la infraestructura estatal para su desarrollo, inhibiéndose de este modo una producción enteramente libre. El mercado interno se origina en excedentes domésticos y artesanos. En efecto, los testimonios de Deir el-Medina sugieren que se dio un crecimiento mercantil, en el que bienes derivados de la producción doméstica y artesana se sumaron a las raciones entregadas. Lamentablemente, no hay información cuantitativa comparable que permita evaluar la magnitud de tales intercambios, aunque se reconoce que funcionarios estatales de modo individual podían adquirir diversos bienes en forma simultánea. La apropiación individual de bienes se refleja en la compra a través de equivalentes aunque no equivalentes universales. Es probable que los funcionarios dispusieran de bienes recibidos por recompensa real e incluso derivados de la acumulación de sus propiedades.

Con todo, se distingue un proceso de circulación de bienes que excede la producción doméstica, y pueden advertirse así relaciones sociales y económicas derivadas de esta disponibilidad de excedentes en los centros metropolitanos.
116. P. Turín $1895+2006=$ Papiro Turín de Tasación: Gardiner (1948: xiii-xiv, 35-44; 1941: 19-73; 127-185); Pleyte y Rossi (1869-76: pls. 65, 100, 155 ; 156; 157; vs. pl. 96); Katary (1989: 169-182). 117. Papiro Amiens: Gardiner (1948: vi-vii, 1-13; 1941: 37-56, pl. 7); Katary (1989: 184-192). Otras fuentes relativas al transporte de grano en Katary (1989: 192ss.). 118. Por ejemplo las Ilamadas huelgas durante el reinado de Ramsés III: Edgerton (1951: 137-145); Eyre (1979: 80-91); Janssen (1979a: 301-308); Frandsen (1990); Janssen (1992).

119. Véase Janssen (1975); Cooney (2007); Zingarelli (2010: 53-67). 120. Estos ingresos podían ser aún más altos que las raciones (Lesko, 1994: 21). Cooney (2006) propone que los artesanos de Deir el-Medina trabajaban en "talleres informales", donde ellos producían un ingreso en el sector privado. Ella afirma (2006:44) que ellos podrían haber trabajado en especializaciones formales jerárquicas, usando su reputación para ganar clientes y tener acceso al material. Se basa en lo que llama registros internos de los talleres. Así, de acuerdo a Cooney, evidencia contextual y circunstancial de la organización del trabajo apunta al trabajo en un lugar determinado más que a un trabajo individual. Sin embargo, numerosas transacciones nos permiten reconocer intercambios individuales de bienes que hacen referencia a trabajo parcial (pintura, decoración, intercambio de pimientos). 
121. Janssen (1975: 546) considera que en cierta forma unidades como seniw, deben y khar eran de hecho dinero.
Y si bien en períodos precedentes se distinguen algunas formas aisladas de este tipo, la mayor parte de los intercambios son trueques, es decir bienes por bienes y son reconocibles como extensión de actividades domésticas y/o cercanas a actividades de aldeas/ciudades, de funcionarios estatales y/o ligadas a instituciones religiosas o funerarias como los templos.

Aunque los patrones de valor han sido usados desde el Reino Antiguo, es dable reconocer un incremento del movimiento de bienes en el período ramésida y el uso de patrones de valor en metal en Deir el-Medina. Permítasenos considerar entonces que esas unidades de medida eran proto-dinero, ${ }^{121}$ e incluso cuando no había moneda correspondiente a una forma de cambio, en algunos intercambios fueron usados equivalentes no generales.

La circulación metálica en primer lugar implica la introducción de estos metales por el estado y en segundo lugar su posterior utilización en el circuito interno como equivalentes, aunque no siempre estuvieron físicamente presentes en las transacciones. Una de las maneras posibles por las que los funcionarios y militares podrían obtener metales, especialmente oro y plata, fue a través de recompensas desde la Dinastía XVIII. Además, los metales preciosos robados fueron oro y plata y el objetivo era intercambiar bienes productivos como grano y animales. Este proceso circulatorio estaba de acuerdo con la práctica de intercambio de equivalentes realizada en Deir el-Medina. La avaricia para el oro, plata e incluso cobre y bronce no debe sólo considerarse como una manera de conseguir mercancías lujosas, pero también debe tenerse en cuenta en el proceso económico general al final del período ramésida.

En síntesis la intervención administrativa centralizada no impidió la apropiación individual de bienes en el circuito circulatorio local ni evitó determinados mecanismos acumulativos. Aunque éstos tuvieron lugar en los centros metropolitanos donde residía la elite. No es del todo excepcional que esta circulación se haya generado por la disponibilidad de excedentes en el ámbito de las operaciones de los grupos dominantes. El dirigismo económico de la monarquía fue compatible con el proceso de acumulación e intercambio privado. Repetimos que el estado niega la acumulación privada pero al mismo tiempo la habilita como efecto secundario de su funcionamiento que es el dominante.

La existencia histórica de comercio y dinero no puede ser ligada a un fenómeno moderno. La fuerza resultante en una sociedad mercantilista no puede ser asignada a los mercados de las clases dominantes en una sociedad con un modo de producción basado en la apropiación primaria de la llamada comunidad superior. Pero por cierto, puede distinguirse un desarrollo mercantil durante el Reino Nuevo implicando el uso de protodinero. Remitiéndonos a Marx serían las llamadas categorías antediluvianas del capital. Son las formas aparentes de ciertas relaciones sociales y económicas dadas en otros modos de producción, pero son falsas expresiones de la acumulación privada dado su origen que no es más que la derivación de la propiedad estatal o de formas incompletas de propiedad individual.

Por otro lado, también, durante el Reino Nuevo se distinguen formas extractivas diferenciales en relación a los esclavos, en su mayoría apropiados en las guerras de conquista en el marco de la explotación de tierras especialmente 
ligadas al templo. Y si bien estos cambios sociales no reemplazan las formas previas, crean nuevas formas de sujeción. Esta explotación del trabajo esclavo no puede llegar a ser la relación de producción dominante debido a la ausencia de propiedad privada plena de la tierra y por la posibilidad de disponer de manera permanente de agricultores a través de la corvea. El trabajo esclavo se insertó en los intersticios del trabajo y la explotación agrícola egipcia sin llegar a constituir la base del sostenimiento de las clases dominantes.

Se advierten en la documentación formas de propiedad de trabajadores esclavos en las ciudades/aldeas, especialmente la relativa a conflictos entre los responsables de las ciudades y otros funcionarios estatales como por ejemplo reclamos por niñas esclavas de un jefe de trabajadores a un intendente de una ciudad. Asimismo se describen ${ }^{122}$ transacciones de alquiler de esclavos por días y a altos valores en equivalentes en metal, incluso transacciones durante una década. ${ }^{123}$ Es probable que los trabajadores fueran propiedad de la ciudad/aldea o de individuos (véase Thédoridès, 1968), pero de algún modo participan de las transacciones integrantes de instituciones como por ejemplo un pastor de un templo (literalmente casa). Acordamos con Navailles y Neveu (1989) quienes propusieron que eran las instituciones (el faraón, los templos, la aldea) las que poseían esclavos y los atribuían nominativamente a ciertos particulares. De este modo, los esclavos podían trabajar sucesivamente una cantidad de días para uno u otro titular temporal, siendo la cesión renovable mensualmente, anualmente o incluso durante una década, y esto podría justificar el alto valor estipulado en las transacciones. Es posible también reconocer la heredabilidad de estos derechos sobre días de trabajo de ciertas familias. ${ }^{124}$

El intercambio de esclavos y de parcelas de tierra es un fenómeno en especial relativo a la circulación y es significativo que sólo está documentado en áreas metropolitanas como Tebas, Kahun, Gurob y otras ciudades importantes. Este proceso de ingreso del trabajo en la circulación es limitado y secundario respecto de la esfera de la producción y de la apropiación del trabajo humano excedente por las clases dominantes.

\section{V}

Marx reconoce al estado asiático como despótico. ${ }^{125}$ No carente de conocimientos empíricos o evidencia como se ha postulado, sino influido como hombre de su época de conceptos sobre el gobierno de estado. ${ }^{126}$ La categoría de despótico o despotismo tiene una raíz valorativa, inspirada en la Ilustración ${ }^{127}$ contra o a favor de las monarquías absolutas europeas. ${ }^{128}$ De ahí, el calificativo de despóticas a aquellas monarquías fundadas en el poder del rey y que no admitían otro tipo de poderes. Además el desarrollo del concepto de despotismo coincide con su extensión a las monarquías de Oriente como un todo. ${ }^{129}$ En Oriente además el déspota como persona se funde con la comunidad suprema y las concesiones se realizan en él como padre de muchas comunidades, para su glorificación y para la del dios. ${ }^{130} \mathrm{Si}$ pensamos la realeza egipcia, ésta basa su dominio territorial, sobre la propiedad y sobre la población, incluso sobre las aldeas en fundamentos míticos. La forma política más evidente de este modo es la monarquía
122. Papiros de Kahun de la Dinastía XVIII: Griffith (1898); Gardiner (1906).

123. Ostracon Gardiner 12: Allam (1973: 177, no. 174); Černý y Gardiner (1957: 16, pls. 54-54a, no. 1); Kitchen (1981: 219-220). 124. Véase Ostracon Hierático 51,2 del período de Ramsés II. También identificado como Ostracon Gardiner 90 y Ashmolean Museum 90: Allam (1973: 68-69, no. 165); Mc Dowell (1993: 23-25). 125. Se dice que refiere al estado o al déspota como individuo o equipara ambos términos (Zamora, 1997: 12 n. 1).

126. O'Leary (1989: 83) apunta a las diferencias que establece Marx entre el despotismo asiático y los estados modernos y sus críticas a Hegel.

127. No obstante, Marx cuestiona la teoría del despotismo de Montesquieu argumentando que no es posible distinguir entre monarquía, despotismo y tiranía (O’Leary, 1989: 84).

128. Hobbes es el primero en recomendar el poder despótico como una forma normal y adecuada de soberanía. A partir de Anderson (1998 [1974]: 477).

129. Es notable el análisis de Anderson (1998 [1974]: 477 ss.) sobre los orígenes de la noción de despotismo asociada con Asia desde Aristóteles, más tarde inspirada en la proximidad del poderío turco, surgió con el renacer de la teoría política en el Renacimiento y hasta la era de la llustración, cuando los viajes y descubrimientos coloniales ofrecieron una formulación más sistemática.

(continúa en página 109)

130. “Una parte de su plustrabajo pertenece a la comunidad suprema, que existe en último extremo como persona, y este plustrabajo se manifiesta como tributos, etc., como en trabajos comunes para la glorificación de la unidad, en parte para la glorificación del déspota, en parte para la del sistema tribal ideal, es decir, de dios" (Marx, 1984 [1965]: 86). 
131. Ya hemos mencionado la importancia de la literatura política durante el Reino Medio. Sobre la relación entre literatura y política durante el Reino Medio egipcio véase Posener (1956). Sobre la discusión acerca del uso del término "propaganda" en relación con estos documentos escritos con contenido político ver Baines (1996: esp. 354). También Assmann (1999: 1-15). 132. Estaba interesado en describir

los rasgos económicos y sociales más que el sistema político según O’Leary (1989: 132).

133. No obstante ello, O'Leary (1989: 83-84) señala que en los tempranos trabajos de Marx

(1843-44) se plantea la noción de despotismo, en un sentido más bien polémico y no analítico, sin diferenciar entre la monarquía feudal y el despotismo oriental. Sofri (1969: 19-20) por su parte, considera que en esa época Marx mira a Asia con ojos hegelianos. 134. Estos artículos fueron escritos a lo largo de varios años y se referían especialmente al impacto político, militar y social del imperialismo británico en India y China. Uno de los más significativos es "El dominio británico en la India", publicado en Junio de 1853.

135. Hasta mediados de la década de los años 50, éste fue un diario de la izquierda whig, para luego pasar a ser el órgano del Partido Republicano.

136. Para un mayor desarrollo de este tema véase Sofri (1969: 25-39).

Sofri explica allí las razones del

interés de Marx en la India en

ese período y el menor espacio

dedicado por ejemplo a la historia

de China. Igualmente cree Sofri (1969:76-77), y coincidimos en esta consideración, que sería erróneo pensar que "Marx veía a la China y

la India de su tiempo en ejemplos

concretos del modelo "modo de

producción asiático"”, aunque

retuvieran trazos visibles. En el

capítulo sobre las consideraciones

históricas del capital comercial del

libro III de El Capital propiedad comunal en India y China.

137. Según Sofri (1969: 70), treinta años después, veía Marx la posibilidad que la revolución y el progreso autónomo llegara de manos de la comuna aldeana rusa. No obstante, en los 50 pensaba Marx en la revolución industrial y el capitalismo destruyendo las comunas de la India y ya en los 80 tenía la convicción de poder saltearse al capitalismo. centralizadora comprendida por los occidentales como despótica. El rey en Egipto, llamado por los griegos faraón "casa grande", es él mismo un dios o hijo del dios sol (Ra) abarcando su poder dominios terrenales y divinos. Este discurso mítico no carece de la violencia propia del estado representado en la propia figura del rey masacrando o aplastando al enemigo, aunque también dándole el aliento de vida a los súbditos si lo creía conveniente. Esta forma política se corresponde con las relaciones dominantes de producción y se sostiene durante milenios, aunque varíen las expresiones de legitimidad ${ }^{131}$ y se desarrollen nuevos mitos que den sustento al poder divino del rey (por ejemplo las teogamias del Reino Nuevo: Campbell, 1912 y Naville, 1896).

Marx no desarrolla las formas políticas y sociales del despotismo, ${ }^{132}$ más bien describe la India bajo la dominación británica remitiendo al "despotismo asiático" y "despotismo oriental". ${ }^{133}$ En las Formen prácticamente no usa el término porque se centra en las formas de propiedad asiáticas pero de algún modo describe y adscribe estas formas dentro de lo que llama despotismo oriental. Es decir corresponden a determinadas relaciones de propiedad y de producción formas políticas, extraeconómicas que son caracterizadas como despóticas.

Si retornamos a 1853, cuando Marx colaboraba en el New York Daily Tribune, ${ }^{134}$ un periódico republicano americano, ${ }^{135}$ as everaba que en los departamentos de Asia había tres de gobierno: de Hacienda, o el saqueo del interior; de guerra o saqueo del exterior; y el departamento de obras públicas (en Marx, 1979 [1853]: 127). Y si bien dadas las condiciones del clima y territoriales menciona que las bases de la agricultura oriental son la irrigación artificial mediante canales y trabajos de irrigación, tiene claro que "en Egipto e India, inundaciones son usadas para fertilizar el suelo..... En su comparación con Occidente encuentra que todos los gobiernos asiáticos tuvieron a su cargo la organización de las obras públicas. Nótese que esta circunstancia más la concentración en pequeños centros que congregaban la unión entre la agricultura y la artesanía originaron un sistema social llamado sistema de aldea. Este sistema era el que daba a cada una de estas pequeñas agrupaciones su organización autónoma y su vida distinta y fue destruido por el vapor y el comercio inglés. Esto es lo que le interesaba destacar valorativamente a Marx en relación a la India bajo dominación británica: la contradicción entre esas unidades/comunidades rurales que considera "laboriosas, patriarcales, inofensivas e idílicas", pero características de una vida sin dignidad, estática y vegetativa que constituyeron al mismo tiempo una sólida base para el despotismo oriental, sesgado por la superstición y privado de todo cambio histórico. ${ }^{136}$ Justifica Marx que el cambio llegue de manos de Inglaterra y a pesar de reconocer sus intereses más mezquinos, concluye que "todo lo que pudo haber sido los crímenes de Inglaterra fue el instrumento inconsciente de la historia en lograr esa revolución". ${ }^{137}$ La idea de la doble misión de Inglaterra: destructiva y al mismo tiempo regeneradora se encuentra presente en este artículo de Marx. No obstante ello, no debe pensarse en una única vía de disolución de la propiedad comunal "primitiva" como Marx mismo expresa sobre la India (1965 [1867]: 56 n. 31).

Contemporáneamente, en las cartas cruzadas, Marx y Engels intercambian ideas sobre Oriente. En la carta del 2 de junio de 1853 (Marx, 1983 [1853]: 330 
ss.), Marx toma la descripción del sistema militar de las ciudades orientales hecha por Francois Bernier en Voyages contenant la description des états $d u$ Grand Mogol y subraya que el ejército está obligado a seguir al rey, quien es el solo y único propietario de toda la tierra. Asimismo, enfatiza que la forma básica de todos los fenómenos orientales, de acuerdo a Bernier en Turquía, Persia e Indostán, debe hallarse en el hecho que no existía propiedad privada de la tierra, como ya oportunamente analizamos. Engels (1983 [1853]: 335 ss.) le contesta -el 6 de junio de 1853- que en efecto la ausencia de propiedad de la tierra es la clave para la comprensión de todo Oriente. Y propone que son motivos ecológicos y climáticos los que explicarían tal ausencia (véase Godelier, 1977: 36). El riego artificial es la condición primera de la agricultura y esto es cosa de las comunas, de las provincias o del gobierno central. Aquí señala, como reproduce Marx en el artículo del New York Daily Tribune unos días después, que son tres departamentos de gobierno: de finanza, o el saqueo del interior; de guerra, o el saqueo del exterior; y el departamento de trabajos públicos. En su respuesta -el 14 de junio de 1853- Marx explica el carácter estacionario de Asia debido a las obras públicas del gobierno central y a la división del imperio en aldeas que tenían una organización separada, aunque cuenta la existencia de pocas grandes ciudades. Quiere explicar el fundamento de la dominación británica y la llegada de la industria a Oriente y lo encuentra en el estancamiento del despotismo asiático. Respecto de la primera condición, advertimos que Marx resalta tal estancamiento debido a las obras públicas del gobierno central y omite el postulado de Engels referido al papel de las comunas y las provincias en el riego artificial. La segunda condición: la presencia de comunidades autosuficientes sobre la base de la unión doméstica de la agricultura y manufactura será desarrollado en las Formen y considerado central en su disquisición. Además en las Formen Marx retomará la idea de la ausencia de propiedad jurídica en medio del despotismo oriental (aquello que Engels escribía en la carta del 6 de junio de 1853) y de la existencia de esa propiedad comunitaria que contiene las condiciones de reproducción y plusproducción. ${ }^{138}$ Pero quizás la diferencia, no menor, respecto al contenido de las Formen sea que en la correspondencia y el artículo periodístico no estará preocupado en explicar ciertos rasgos de las sociedades asiáticas sino más bien definir dialécticamente formas previas al desarrollo del capitalismo (véase O'Leary, 1989: 102).

Luego volverá Marx (1965 [1867]: 357) en El Capital brevemente sobre la idea que no es sólo la fertilidad del suelo o el clima sino el trabajo de la mano del hombre a gran escala apropiándose de las fuerzas naturales y ejemplifica con los trabajos de irrigación en Egipto. No obstante ello, en la nota concentra la atención en la importancia de la regulación de la crecida del Nilo y la necesidad de realizar observaciones y conocer cálculos astronómicos, actividad que estaba a cargo de los sacerdotes, quienes eran a la vez los administradores de la agricultura (Marx, 1965 [1867]: 360 n. 6).

Una cierta tensión parece observarse en los postulados de Marx en estos escritos de 1853 en torno a las condiciones y organización de producción de las aldeas ${ }^{139}$ y la organización atribuida al estado respecto de grandes trabajos de irrigación. Esto podría en cierta medida aclararse en especial si prestamos atención a las Formen cuando Marx destaca la apariencia de la obra del gobierno despótico respecto a las "conducciones de agua" sostenida en las condiciones colectivas
138. Entiendo que Hobsbawm plantea que dado que no conocían las Formen, algunos estudiosos señalan que el sistema oriental se caracterizó por la ausencia de propiedad de la tierra debido a la excesiva centralización y obras públicas e irrigación a partir de las cartas cruzadas y los artículos de Marx sobre la India. Hobsbawm (1984 [1965]: 40-41) indica que Marx sostuvo en las Formen la idea de la unidad de manufactura y agricultura en las aldeas. Con diferente interpretación véase Soriano Llopis (2007: 25).
139. Recordemos que omite la propuesta de Engels sobre el papel de las comunas y de las provincias en la cuestión del riego. 
140. Su correlato ritual lo encontramos en una representación muy temprana que muestra a un rey abriendo un canal de irrigación, realizando un rito de inauguración (cabeza de maza de Escorpión, ca. 3000 a. C.).

141. Se ha asumido que en el Fayum Sesostris II proyectó convertir un área de marismas en tierras aptas para la agricultura que incluía un dique y canales que lo conectaran con Bahr Yusef o Gran Canal (mr $w r)$. Ello estaba en relación con los monumentos funerarios construidos en la región. Véase Callender (2007 [2000]: 218) quien acepta la realización de los trabajos pero duda de adscribirlos a Sesostris II. De todos modos, se carece de evidencias firmes que sostengan la realización de tales trabajos de irrigación (Diego Espinel, 2011: 236).

142. Estela Berlín 14334: Andreu (1991: pl. 2, fig. 1); Roeder (1913: 122). Estela Florencia 6365: Varille (1935-8: 554-555); Bostico (1959: 24-25, pl. 18).

143. A partir de Moreno García (2004a: 48). También de Eyre (1999: 34).

144. Sobre la falencia de la hipótesis causal hidráulica y un análisis sobre el Egipto antiguo, véase Cardoso (1982: 14-25). de apropiación de la naturaleza (a partir de O'Leary, 1989: 97-98). Evidentemente en las Formen entiende que tienen importancia por ejemplo los acueductos llevados a cabo por el estado en la medida que implica apropiación del trabajo de las aldeas: "las condiciones comunes de la apropiación real mediante el trabajo, conducciones de aguas -muy importante en los pueblos asiáticosmedios de comunicación, etc., se presentan entonces como la obra de la unidad - del gobierno despótico que está por encima de las pequeñas comunidades" (Marx, 1984 [1965]: 87).

En este punto si ponemos la atención solo en el Egipto antiguo, la irrigación natural del Nilo sobre la tierra cultivable durante varias semanas generaba cuencas naturales a lo largo del curso del río y permitía en torno a octubre la siembra de trigo, cebada y lino. Ello supone la capacidad de las comunidades campesinas de mantener en buenas condiciones los canales de conducción de agua y regular aperturas y cierres en los diques que permitían la circulación del agua (véase Moreno García, 2004a: 46).

Con todo, la fiscalización del estado respecto de las crecidas del río Nilo y la superficie del terreno que sería inundada parece haber sido crucial para el cálculo de los impuestos (Moreno García, 2004a: 46). Quizás a ello se deba que los textos registren con detalle los distintos tipos de tierra y de rendimientos, constando así una rica y compleja lexicografía relativa a tipos de suelo sobre todo en los censos de las tierras que servían a los efectos de establecer los impuestos (Moreno García, 2004a: 51). A este tenor, se desarrollan una serie de conocimientos de cálculos astronómicos y medidas por parte de sacerdotes y escribas que contribuyen a estos registros.

Sin embargo, el estado interviene en el acondicionamiento de $\operatorname{campos}^{140} \mathrm{y}$ las comunidades locales suministran los trabajadores para llevarlo a cabo. El incremento de la tierra cultivable a través de irrigación artificial ${ }^{141}$ parece haber sido una opción desde los inicios de las dinastías faraónicas (Butzer, 1976: 20) aunque ello no implicó la realización de obras hidráulicas masivas o complejos sistemas de canales recién identificables en la época greco-romana y los siglos XIX y XX (Moreno García, 2004a: 47; Eyre, 1999: 34, 2004: 157-176) que permitieran un sistema de irrigación permanente y no estacional (Cardoso, 1986: 13). Como señala Eyre (2010: 292) "la conversión de este paisaje salvaje en un régimen de irrigación artificial disciplinado fue obra de los siglos XIX y XX". Algunos funcionarios subrayan en sus autobiografías haber llevado adelante la construcción de canales y durante el primer período de fragmentación del estado también los hombres locales subrayan su intervención en la construcción de canales, acequias (por ejemplo, véase Griffith, 1889: 11, pl. XV) y cisternas, ${ }^{142}$ así como en el uso del agua cercando los campos y las zonas elevadas. ${ }^{143}$ No cabría atribuir una relación causal directa entre la "agricultura hidráulica" y las lógicas políticas y las relaciones sociales (Butzer, 1976: 110), pero tampoco puede desestimarse la productividad y organización agrícola en relación con las acciones del estado, en particular en zonas poco propicias.

La tesis de Karl Wittfogel es muy otra, se basa en el despotismo hidráulico/ oriental $^{144}$ como un sistema que requiere un control gerencial. De este modo, 
el aparato de estado deriva su poder de la necesidad de administración continua y control de irrigación (Hindess y Hirst, 1975: 217; O'Leary, 1989: 140). Es escaso este espacio para discutir en profundidad el problema del despotismo hidráulico en los términos interpretados por Wittfogel, por consiguiente diremos que su atención está enfocada en el despotismo, como señala Krader, en el lado político del problema. ${ }^{145}$

Por su parte, Godelier (1971: 43-44) propone un modo de producción en el que una aristocracia dispone de un poder de estado y asegura las bases de su explotación de clase mediante la apropiación de una parte del producto de las comunidades, aunque insiste en la existencia de grandes trabajos que condicionarían la presencia de una burocracia y de un poder absoluto, centralizado, lo que se denomina anticuada y vagamente despotismo. No obstante ello, piensa en una tipología de diversas formas del modo de producción asiático con o sin grandes trabajos, con o sin agricultura, subrayando la emergencia de una primera estructura de clase de contornos imprecisos y la apropiación regular del trabajo de las comunidades, así como un desarrollo de las fuerzas productivas en esas civilizaciones como lo demuestra el dominio del hombre sobre la naturaleza a partir del uso de los metales, las nuevas formas de arquitectura, el cálculo, la escritura, etcétera (Godelier, 1977: 152; 1971: 44-45).

La importancia de la supervisión e intervención en la irrigación parece deberse a la derivada acumulación del estado y su política de fiscalidad. Los grandes trabajos como las grandes construcciones arquitectónicas, son realizables en la medida que el estado pueda proveer de recursos nacidos de la apropiación del excedente y su administración, y sobre todo la utilización de trabajo humano y ello es notable sobre todo en los períodos de centralización política. ${ }^{146} \mathrm{~A}$ partir de las primeras dinastías el monumento en el Egipto faraónico como dice Bard (2007 [2000]: 105) es símbolo del enorme control ejercido por la corona. Cuando se fragmenta el estado, durante los períodos de descentralización, llamados intermedios ${ }^{147}$ desaparecen las grandes obras y construcciones y los recursos parecen haberse administrado a nivel local y regional.

\section{VI}

Lo más complejo de replantear aquí es el calificativo de asiático, quizás porque Asia asome como una abstracción ligada a determinados rasgos de valor negativo, como despótico, cerrado, estancado y expresados en torno a la singularidad de los procesos en Oriente disímil a Occidente.

No obstante, como señala el propio Said (1977: 6) "orientalismo, por lo tanto, no es una fantasía Europea sobre el Oriente, sino un cuerpo creado de teoría y práctica en la que, durante muchas generaciones, ha habido un considerable material producido". Egipto se incluyó en ese Oriente en el discurso académico, por su propia historia más vinculada al desarrollo urbano y estatal del Cercano Oriente Antiguo que al sustrato africano del que también formaba parte (Cervelló Autuori, 1996: 33 ss.). Esta construcción histórica "Cercano Oriente Antiguo" nacida en Europa, designa regiones y sociedades diversas y a menudo
145. De acuerdo a Krader (1972: 115, n. 53), Wittfogel convierte las categorías de despotismo y totalitarismo en estructuras económicas, como parte de sistemas gerenciales o semi-gerenciales. Véase Bartra (1975: 23). Véase Sofri (1969: 133-147) sobre el libro de Wittfogel y las críticas a sus tesis.

146. Explica Jones (1852: 77-8) que "para mover las colosales estatuas y las enormes masas, cuyo transporte produce estupor, usaban prodigiosamente casi tan sólo trabajo humano...El poder de dirigir aquellas masas ha dado origen a aquellas obras titánicas". Marx (1965: 228-229) cita este párrafo para explicar la eficacia de la cooperación simple. 147. Bibliografía general sobre los períodos intermedios: Primer período intermedio ca. 21602055 a.C.: Seidlmayer (2007 [2000]); Franke (2000: 526-532); Moreno García (2011a); Willems (2010: 81-100). Segundo período intermedio ca. 1650-1550 a.C.: von Beckerath (1965); Bourriau (2007 [2000]); Ryholt (1997). 
148. Sobre una crítica a la posición de Said, véase Ah$\operatorname{mad}$ (1992: 221-242). 149. Sobre la influencia de Hegel y el cuestionamiento al espíritu occidental como de cambio y desarrollo, véase Hindess y Hirst (1975: 203-206). su visión conjunta y global ha desechado sus particularidades. Paradójicamente los estudios lingüísticos y las exploraciones arqueológicas, en su mayoría impulsados por europeos, en particular desde el siglo pasado han dado lugar al conocimiento académico de "Oriente". De todas maneras, no se trata de señalar como Said que a Marx le era más fácil ilustrar la teoría a partir del Oriente colectivo como una declaración profética o reducir su atención en Oriente a un requerimiento de redención occidental. ${ }^{148}$ Sí se puede reconocer un problema en la categoría de asiático, por la fuerza dada a los factores geográficos en el desarrollo histórico ${ }^{149}$ y por ser la única noción de modo de producción ligada a un espacio determinado (Sawer, 1977: 2).

Ya Godelier (1971: 41-42) había propuesto abandonar el calificativo asiático porque el fenómeno de la transición de una sociedad sin clases a una sociedad clasista es reconocible en distintas épocas y espacios geográficos. Sin embargo, los propios trabajos de Marx y Engels aluden a Asia en general aunque muchas veces se nombra a Turquía, Persia, Afganistán, Tartaria, Arabia, Malasia, Isla de Java, China, India, Indostán, Mesopotamia y Egipto pero también a civilizaciones americanas como México y Perú. La crítica de la restricción geográfica (Chesneaux, 1983 [1969]: 110; Godelier, 1971: 41-42; Hindess y Hirst, 1975: 185-87) carece de sentido dado que el propio Marx en las Formen no limita la forma asiática a determinados espacios y señala la complejidad de los procesos de disgregación o transformación de antiguas relaciones dependiendo de circunstancias históricas y geográficas, de modo que no estaría limitada tal noción como se ha pretendido (Sofri, 1969: 46-48).

Por otra parte, la aparición del feudalismo se ha asociado históricamente a Europa y se ha reconocido como tal la singularidad de Occidente y su desarrollo hacia el capitalismo industrial (Goody, 1996: 3). Como señala Goody (1996: 10) la idea de la singularidad única de Occidente surge en relación a la "maldición" capitalista. Este autor cuestiona los enfoques que abordan la cuestión desde la racionalidad occidental, del comercio occidental y los vínculos entre los fenómenos comprendidos como "modernización", "industrialización" y el mismo "capitalismo". Como admite Goody el binarismo está presente en las visiones del mundo, la cuestión es no recrear una falsa evaluación comparativa entre Oriente y Occidente.

Tampoco resuelve el problema reconocer en Oriente un modo de producción feudal conviviendo con otros modos; en ese caso ni siquiera gozaría de algún tipo de singularidad y también seguiría estando en un nivel previo de desarrollo a "Occidente". Como hemos expuesto para el Egipto faraónico, uno de los espacios considerados por Marx como parte de ese Oriente, es factible analizar ese estado antiguo a partir de la noción de modo de producción asiático. La generalización de ese modo a espacios históricos comprendidos como Oriente es una cuestión que debe comprenderse en torno a una determinada tradición occidental. No obstante ello, la restricción geográfica estaba ausente en la interpretación del propio Marx, quien cuando pensó en la transición de sociedades "primitivas" o sociedades sin clases con un modo primitivo o comunal a una sociedad de clases, a estados prístinos, ubicó este fenómeno en Oriente porque de hecho, los primeros estados surgen primero en Egipto, Mesopotamia, China, India aunque luego también en América. Así, la forma 
asiática era la más cercana a la comunidad primitiva, era una primera forma en relación a las formas antigua y germánica. Pero, conviene Marx que la forma asiática ha sufrido variaciones de carácter histórico y geográfico (Sofri, 1969: 43-54). Esto habilita suponer que lo expuesto por Marx en las Formen sobre el modo asiático se acerca más a un proceso complejo de relaciones entre la comunidad superior y las comunidades aldeanas que se asocia a los primeros estados en "Oriente" y de ahí su calificativo, sin perjuicio de que estas relaciones puedan identificarse en otros espacios geográficos y otras épocas históricas.

\section{VII}

Como se ha argumentado antes, la lógica estatal en el modo de producción asiático es preeminente y la relación con las aldeas se caracteriza por formas extractivas y de explotación. Esta relación primera de apropiación es la que define el modo de producción, cuyos elementos constitutivos remiten a formas de propiedad. De esta manera, en las Formen, se destaca que el estado aparezca como el propietario superior o el único propietario, haciéndose acreedor del plustrabajo de las aldeas (aunque cada familia campesina pueda cultivar su propia parcela) y del trabajo común que deben realizar para exaltar al déspota real o a la divinidad.

En la formación económico-social que hemos considerado se adivinan las formas de propiedad de las aldeas por la fuerte identidad local y por la economía autosuficiente así como también por la propiedad compartida y por el requerimiento de las instituciones estatales de proveer trabajo directo o entregar plustrabajo. No obstante, la intervención estatal es creciente creándose instalaciones agrícolas en distintas zonas desde el Reino Antiguo y adquiriendo preeminencia los templos hasta el Reino Nuevo cuando se convierten en los mayores propietarios de tierras, en particular los localizados en centros políticos administrativos. La propiedad supuesta o aparente del estado se transforma en una propiedad real y efectiva. De este modo, las propiedades de las aldeas terminan en algunas regiones yuxtaponiéndose a estas tierras institucionales.

La transformación de estos vínculos con las comunidades no descompone sus rasgos esenciales basados en la producción agrícola y la manufactura, más allá de la diferenciación y jerarquización visible entre jefes de aldeas, las elites locales y las instituciones funerarias con sus lógicas de funcionamiento específico pero de algún modo limitadas por la corona. La continuidad es visible en un estado que mantiene su forma política y sus mecanismos de explotación y dominación y es correspondiente al modo de producción dominante. El no colapso del estado faraónico que se sostiene, la pervivencia de formas de funcionamiento por milenios ha conducido a caracterizar estas sociedades como estancadas, sin movimientos. Ciertamente, pueden reconocerse cambios políticos, económicos y sociales pero que no socavan el modo dominante de apropiación y los mecanismos de explotación del estado.

Los llamados períodos intermedios o transicionales ponen de manifiesto las luchas entre elites regionales y permiten identificar categorías sociales 
intermedias y contradicciones de clase aunque también expresiones de estatus que se manifiestan en crisis políticas y económicas que dan cuenta de una cierta fragmentación estatal. Tales procesos de crisis no socavan las relaciones dominantes de producción. Como hemos señalado antes, relaciones clientelares y la lógica del patrón son comprensibles como prácticas reconocibles convivientes con la lógica que impone el propio estado.

En este modo, de acuerdo a las Formen, el individuo está entonces de hecho carente de propiedad o la propiedad parece estar intercedida por medio de una concesión [Ablassen] de la unidad total. De hecho, en el Egipto faraónico la entrega de tierras a altos funcionarios por el rey como retribución de funciones y servicios se documenta desde el Reino Antiguo. Formas de propiedad familiares se registran en distintos períodos de la historia faraónica, yuxtapuestas a fundaciones funerarias y religiosas. La aparición de un tipo de propiedad individual indica la convivencia de relaciones adyacentes a las formas de propiedad dominante pero no genera una aristocracia terrateniente hereditaria que pueda disputar la primacía y dominancia al estado central. Es decir que la aparición de tal tipo de propiedad no transformó las formas dominantes de explotación sobre las comunidades y sobre los dominios de la corona. De los contenidos mítico-políticos que se corresponden a tales formas emanan los fundamentos de la realeza y la función del rey como integrador de la naturaleza y el cosmos.

Los postulados de 1853 van en un sentido similar, como la alusión al sistema de aldea como un rasgo de las sociedades asiáticas aunque también de la ausencia de propiedad privada. La mención del sistema de aldea y la inexistencia de propiedad privada si bien en conexión con las proposiciones de las Formen se reducen en su exposición analítica por el tipo de publicación en las que se hallan (New York Daily Tribune y cartas cruzadas) y por tratarse de la India o de un Oriente como un todo, subrayándose la pervivencia de esos rasgos en sociedades contemporáneas. El único aspecto que se recalca sólo en los escritos de 1853 es la cuestión del riego artificial como condición de la agricultura y un cierto determinismo geográfico dado que explican la ausencia de propiedad privada por motivos ecológicos y climáticos. Se ha sobrestimado tal rasgo dando lugar al despotismo hidráulico como idéntico al modo de producción asiático, cuando en las Formen en realidad se enfatiza que las condiciones comunales de apropiación real a través del trabajo, tales como acueductos, entre otras obras por ejemplo medios de comunicación, etc., aparecerían como obra de la entidad superior que se encuentra sobre las comunidades. La documentación en el Egipto faraónico da cuenta de trabajos de irrigación a nivel local y estatal, pero fundamentalmente de la supervisión e intervención estatal de la irrigación ligada a su política de fiscalidad. Asimismo, los habitantes de las aldeas podían ser convocados para realizar distintos trabajos para el faraón tal como la construcción de un templo o un canal o formar parte del ejército o de una expedición a las minas.

Para explicar la aparición de formas de intercambio derivadas de acumulación individual y de procesos de circulación que pueden incluso permitir transacciones con protodinero se debe reparar en la disponibilidad de excedentes de las clases dominantes, en particular en ciudades de importancia administrativa y/o religiosa. La propia formulación de Marx en las Formen apunta a destacar que 
la realeza y sus más altos funcionarios intercambiaban sus ingresos -productos excedentes- en las ciudades. Estos procesos son identificables en Egipto en el Reino Nuevo en particular en Tebas y Deir el-Medina, la aldea de los artesanos donde se elaboraban bienes funerarios para la elite. También en este período se descubren intercambios de pequeñas parcelas de tierras y esclavos por equivalentes a un bajo valor, en los que intervienen altos funcionarios aunque en intrincadas relaciones con templos o ámbitos domésticos. Los ingresos del imperio derivados a templos y donados a altos funcionarios generaron una mayor disponibilidad de excedentes en el seno de las clases dominantes.

\section{Notas}

2 Mucho más fructífero sería plantear estos problemas a partir de la historia comparada pero carezco de los conocimientos y destrezas específicas. La propuesta de encarar este análisis a partir de la historia del Egipto antiguo se debe a mi formación académica. $\mathrm{O}$ bien discutir los términos en los que fue planteado el concepto de modo de producción asiático es una buena excusa para pensar la historia de Egipto en clave marxista, en la lógica de un proceso histórico y no sólo a partir de la microhistoria. (Viene de página 78.)

4 También en El Capital, volumen I, sección 4 cuando trata sobre el fetichismo de las mercancías dice: "En los modos de producción paleoasiático, antiguo, etc., la transformación de los productos en mercancía y por tanto la existencia de los hombres como productores de mercancías desempeña un papel subordinado, que empero se vuelve tanto más relevante cuanto más entran las entidades comunitarias en la fase de su decadencia". (Viene de página 78.)

6 Por ejemplo Bartra (1983 [1969]: 21-34) despliega la evolución de conceptos asociados, en particular el de despotismo oriental desde Platón y Aristóteles hasta Richard Jones y Hegel. También Anderson (1998 [1974]: 476 ss.) rastrea los orígenes de las concepciones asociadas a los países asiáticos en oposición a los europeos, las cuales habrían influido en la obra de Marx y Engels. (Viene de página 78.)

7 Fue Anderson (1998 [1974]: 568) quien sugirió "dejar que a este concepto (el de modo asiático de producción) le sea dado el entierro decente que merece”. Zaccagnini (1989: 13) se preguntaba irónicamente qué otro modelo heurístico podría proponer un autor como Komoróczy para la interpretación de las formaciones socio-económicas de la antigua Mesopotamia cuando el modo de producción asiático estaba muerto y enterrado. (Viene de página 78.)

8 Especialmente Sofri (1969: 81-103) sobre el período anterior. Una discusión sobre el modo de producción asiático y la extensión de esta categoría al Oriente contemporáneo se da entre distintos estudiosos en Tiflis en mayo de 1930. Unos meses después, en la discusión de Leningrado (1931), por iniciativa de la Asociación de orientalistas marxistas, se pone en juego por un lado el fracaso de la revolución china de 1927 apelando al estancamiento asiático y allí se cuestiona tal posición y su correlato teórico, enfatizándose la defensa de la interpretación feudal, y por otro se sostiene la interpretación de la esclavitud (Bailey 
y Llobera, 1981: 52). Para un análisis detallado y pormenorizado de los argumentos del debate véase Dunn (1982: esp. 7-37). Algunos investigadores siguieron sosteniendo la posibilidad de considerar el modo de producción asiático para Mesopotamia y el Egipto antiguo. Véase Sofri (1969: 117 ss.). Stalin ya no lo menciona en Materialismo dialéctico e histórico de 1938. No obstante, algunos marxistas de habla inglesa, como Namboodiripad (1952), lo siguen mencionando. En un ensayo este mismo autor rescata lo planteado por Marx en las Formen en relación a la India, Namboodiripad (2010: 23-31). (Viene de página 78.)

9 En 1957 fue publicado por Yale University Press, New Haven. La versión en español que utilizamos es la publicada en 1966. Bartra (1975: 28) llama la atención sobre la cantidad de páginas (450) y la cantidad de capítulos (10), subcapítulos (58) y subtítulos (193). Bartra (1975: 21-37) dedica parte de este libro a discutir la teoría de la sociedad hidráulica y los casos históricos que trata refieren al México antiguo; esta sección fue publicada originalmente en la revista Tlatoani, no 21 en 1967. Reseña en Vidal-Naquet (1964). (Viene de página 78.$)$

14 Se distingue él mismo de Haldon señalando que este último considera la distinción entre impuesto y renta como puramente formal ya que ambos son modos de apropiación del excedente, y en este sentido variantes de un modo común de producción: el tributario. Cabe destacar que quien ha desarrollado más ampliamente el concepto de modo de producción tributario es John Haldon (1993). Y como veremos más adelante el nombre de modo tributario fue utilizado también por Amin en el sentido de un modo común de producción y según el mismo Amin el término fue usado en 1934 por Jiro Hoyakawa, un marxista japonés. (Viene de página 80.)

36 "Cuanto más los productos de la comuna asumieron la forma de la mercancía, es decir, cuanto menos fueron producidos para el uso propio de sus productores y más con el propósito de intercambio, más la original división del trabajo primitiva fue sustituida por el intercambio también dentro del comuna; más se desarrollaba la desigualdad en la propiedad de los miembros individuales de la comuna, más profundamente se socavaba la antigua propiedad común de la tierra y más rápidamente la comuna se movía hacia su disolución y su transformación en un pueblo de pequeños agricultores. Durante miles de años el despotismo Oriental y la norma cambiante de conquistar pueblos nómadas pudieron transformar esta vieja forma de comuna; se vio la destrucción gradual de su industria original por la competencia de productos de la industria a gran escala que las condujo más cerca de la disolución" (Engels, 1987 [1878]: 150-151). (Viene de página 84.)

38 Hoffman (1979: 17) caracteriza al Egipto de los faraones como "sociedad de base aldeana". Cardoso (1986: 16 n. 17 y 25-26) además de tomar esta idea de Hoffman, subraya los principios de la "organización aldeana comunitaria". Por su parte, Eyre (1999: 35) sostiene que "Egipto fue probablemente una sociedad aldeana". "El polo doméstico y campesino poseía con toda probabilidad formas propias de organización de los procesos productivos y del espacio, así como prácticas y técnicas agrícolas seguramente distintas a las utilizadas en el sector institucional, con el cual mantenía relaciones determinadas por la fiscalidad del estado (...)" (Moreno García, 2004b: 30). (Viene de página 84.)

39 Autores como Menu y Harari (1974: 125) plantean la organización administrativa centralizada bajo una realeza única en función de dos fuerzas: el dirigismo económico y la persistencia de estructuras comunitarias. Asimismo, Janssen (1979b: 507-508) refiere a la 
estructura económica del antiguo Egipto en base a dos esferas; en la base la economía local de subsistencia: campesinos y artesanos en las aldeas producían la mayoría de los bienes necesarios para la subsistencia y podían intercambiar a través del trueque con sus vecinos. Sobre la base de esta economía de subsistencia descansa una segunda esfera, la redistribución estatal. (Viene de página 84.)

44 Las divisiones artificiales entre reinos e imperios proviene de la convención gestada en el siglo XIX sobre la división de la historia faraónica en imperios/reinos a partir de Bunsen, un investigador prusiano, y adoptada a partir del siglo XX. Como sea, y a pesar de lo fragmentado de la documentación, es indiscutible que durante determinados períodos de la historia faraónica el poder político estatal, en particular el central, fue lo más visible en términos de organización, burocratización y apropiación de un excedente agrícola. (Viene de página 84.)

55 Durante la Dinastía IV la corona se propone la incorporación del Delta y más tarde de una región situada en el Egipto Medio como zonas productora de bienes, roturando y explotando terrenos. Parra Ortiz (2011: 147). (Viene de página 86.)

56 Debemos a Moreno García (2004a: 17) el análisis. En el Egipto Alto y Medio la corona crea los $h w t$, una especie de centros agrícolas y administrativos, que disponían de campos, trabajadores y animales y constituían bases para la fiscalidad estatal (Parra Ortiz, 2011: 184-185). Se crean capillas reales ( $h w t-k 3)$ en distintas localidades con tierras y rentas a disposición de la corona (Moreno García, 1996, 2001). (Viene de página 86.)

57 Eyre (1999: 35) señala que estas comunidades rurales creadas podían ser pobladas con prisioneros de guerra o grupos de inmigrantes y que como dominios proveían al rey y la administración real o a funcionarios estatales. (Viene de página 86.)

6o Redford (1993: 8) establece que "wahyet 'clan, familia' fue aplicado a aquellos pequeños campamentos de grupos parentales". Véase también Spiegelberg (1904: 150); Franke (1983: 219 ss.). (Viene de página 86.)

61 En los textos de Execración whyt refiere a clanes o `3mw "asiáticos" de Biblos. Véase Helck (1971: 53). En la historia de Sinuhé whyt está escrito de diversas formas aunque el determinativo de gente en plural se conserva en todas las palabras (Papiro Berlín 3022: 28, 86, 94, 113, 130, 239, 240). Para otras referencias véase Mazar (1990: 185). (Viene de página 86.)

69 Tal responsabilidad fiscal comunal, delegando responsabilidades en magnates locales intermediarios, es presentada por Eyre (1999: 45) como un problema no fácil de visualizar. No obstante ello, como hemos señalado, son las aldeas y no individuos las que entregan ofrendas a las tumbas del Reino Antiguo. Ibid.: 47. (Viene de página 86.)

129Es notable el análisis de Anderson (1998 [1974]: 477 ss.) sobre los orígenes de la noción de despotismo asociada con Asia desde Aristóteles, más tarde inspirada en la proximidad del poderío turco, surgió con el renacer de la teoría política en el Renacimiento y hasta la era de la llustración, cuando los viajes y descubrimientos coloniales ofrecieron una formulación más sistemática. Sawer (1977: 5 ss.) también analiza cómo esta idea del despotismo oriental ya estaba presente en los griegos, en concreto en Aristóteles quien en Política (3/9) señala que "Hay pueblos que, arrastrados por una tendencia natural a 
la servidumbre, inclinación mucho más pronunciada entre los bárbaros que entre los griegos, más entre los asiáticos que entre los europeos, soportan el yugo del despotismo sin pena y sin murmurar; y he aquí por qué los reinados, que pesan sobre estos pueblos, son tiránicos, si bien descansan por otra parte sobre las sólidas bases de la ley y de la sucesión hereditaria”. (Viene de página 99.) 


\section{Q Bibliografía}

" Ahmad, A. (1992). Marx on India: A Clarification, en: Theory: Classes, Nations, Literatures. Londres: Verso, 221-242.

»Allam, S. (1973). Hieratische Ostraka und Papyri aus der Ramessidenzeit, Urkunden zum Rechtsleben im alten Ägypten, 1. Tubinga: Selbsverlag des Herausgebers.

»Allam, S. (1989). Some Remarks on the Trial of Mose, en: Journal of Egyptian Archaeology 75: 103-112.

»Allam, S. (1990). A New Look at the Adoption Papyrus (Reconsidered), en: Journal of Egyptian Archaeology 76: 189-191.

»Allam. S. (2004). Une classe ouvrière: les merit, en: Menu, B. (ed.), La dépendance rurale dans l'Antiquité égyptienne et procheorientale. El Cairo: Institut Français d'Archéologie Orientale, 123-155.

»Allen, J. (2002). The Heqanakht Papyri. Nueva York: Metropolitan Museum of Art.

"Amin, S. (1976). Unequal Development. An Essay on the Social Formations of Peripheral Capitalism. Sussex: The Harvester Press.

" Anderson, P. (1998 [1974]). El “modo de producción asiático”, en: Anderson, P., El Estado Absolutista. Madrid: Siglo Veintiuno, 476-568.

»Andreu, G. (1991). Deux stèles de commissaires de police (jmy-r šnt) de la Première Période Intermédiaire, en: Cahiers de Recherches de l'Institut de Papyrologie et d'Égyptologie de Lille 13: 18-20.

" Assmann, J. (2005 [1996]). Egipto: Historia de un sentido. Madrid: Abada.

» Assmann, J. (1999). Cultural and Literary Texts, en: Moers, G. (ed.), Definitely: Egyptian Literature (Lingua Aegyptia, Studia Monographica 2). Gotinga: Seminar für Ägyptologie und Koptologie: 1-15.

»Astarita, C. (2000). Historia y ciencias sociales. Préstamos y reconstrucción de categorías analíticas, en: Sociohistórica 8: 13-43.

»Baer, K. (1962). The Low Price of Land in Ancient Egypt, en: Journal of the American Research Center in Egypt 1: 25-45.

»Baer, K. (1963). An Eleventh Dynasty Farmer's Letters to His Family, en: Journal of the American Oriental Society 83/1: 1-19.

» Bailey, A.M. y Llobera, J.R. (1981). The Asiatic Mode of Production: Science and Politics. Londres: Routledge \& Kegan Paul.

»Baines, J. (1996). Contextualizing Egyptian Representations of Society and Ethnicity, en: Cooper, J.S. y Schwartz, G.M. (eds.), The Study of the Ancient Near East in the 21st Century. Indiana: Eisenbrauns, 339-384.

» Banaji, J. (2011). Theory as History: Essays on Modes of Production and Exploitation. Chicago: Haymarket Books.

»Bard, K. A. (2007 [200o]). La aparición del estado egipcio (c. $3200-2686$ a.C.), en: Shaw, I. (ed.), Historia del Antiguo Egipto. Madrid: La Esfera de los libros, 93-125. 
》Bartra, R. (1975). Marxismo y sociedades antiguas. El modo de producción asiático y el México prehispánico. México D.F.: Grijalbo.

» Bartra, R. (1983 [1969]). El modo de producción asiático. Antología de textos sobre problemas de la historia de los países coloniales. México D. F.: Era.

» Baud, M. (1999). Famille royale et pouvoir sous l'Ancien Empire égyptien. El Cairo: Institut français d'archéologie orientale.

"Blackledge, P. (2006). Reflections on the Marxist Theory of History. Manchester: Manchester University Press.

» Blackman, A.M. y Peet, T.E. (1925). Papyrus Lansing: A Translation with Notes, en: Journal of Egyptian Archaeology 11: 284-298.

»Bosticco, S. (1959). Le Stele egiziane dall'Antico al Nuovo Regno. Roma: Istituto Poligrafico dello Stato.

»Bourriau, J. (2007 [2000]). El Segundo Período Intermedio (c.1650-1550 a.C.), en: Shaw, I. (ed.), Historia del Antiguo Egipto. Madrid: La Esfera de los libros, 241-285.

» Butzer, K. W. (1976). Early Hydraulic Civilization in Egypt: A Study in Cultural Ecology. Chicago: The University of Chicago Press.

"Callender, G. (2007 [2000]). El Renacimiento del Reino Medio (c. 2055-1650 a.C.), en: Shaw, I. (ed.), Historia del Antiguo Egipto. Madrid: La Esfera de los libros, 197-240.

»Campagno, M. (2003). El modo de producción tributario y el Antiguo Egipto. Reconsiderando las tesis de Samir Amin, en: Haldon, J. y García Mac Gaw, C. (eds.), Modo de Producción Tributario, Anales de Historia Antigua y Medieval, vol. 35-36: 61-80.

»Campbell, C. (1912). The Miraculous Birth of King Amon-Hotep III. And Other Egyptian Studies. Edimburgo: Oliver \& Boyd.

»Cardoso, C. (1982). Egito antigo. San Pablo: Brasiliense.

»Cardoso, C. (1986). Les communautés villageoises dans l'Égypte ancienne, en: Dialogues d'histoire ancienne 12: 9-31.

»Cardoso, C. (1988). Sociedades do antigo Oriente Próximo. San Pablo: Ática.

»Cardoso, C. (1990). Modo de Produção Asiático. Nova Visita a um Velho Conceito. Río de Janeiro: Editora Campus.

"Cardoso, C. (1993). Hekanakht: pujança passageira do privado no Egito antigo. Niterói: Universidad Federal Fluminense.

"Cardoso, C.F. (2009). Las unidades domésticas en el Egipto antiguo, en: Campagno, M. (ed.), Parentesco, patronazgo y Estado en las sociedades antiguas. Buenos Aires: Facultad de Filosofía y Letras/Universidad de Buenos Aires, 87106.

» Černý, J. (1945). The Will of Naunakhte and the Related Documents, en: Journal of Egyptian Archaeology 31: 29-53.

» Černý, J. y Gardiner, A. (1957). Hieratic Ostraca, vol. I. Oxford: Griffith Institute at the University Press.

»Cervelló Autuori, J. (1996). Egipto y África. Origen de la civilización y la monarquía faraónicas en su contexto africano. Barcelona: Ausa. 
»Chesneaux, J. (1964). Le mode de production asiatique: quelques perspectives de recherche, en: La Pensée 114: 33-55.

»Chesneaux, J. (1983 [1969]). El modo de producción asiático. Antología de textos sobre problemas de la historia de los países coloniales. México D. F.: Era.

" Childe, V. G. (1954 [1936]). Los orígenes de la civilización. México: Fondo de Cultura Económica.

" Childe, V. G. (1942). What Happened in History. Harmondsworth: Penguin Books.

"Cooney, K. M. (2006). An Informal Workshop: Textual Evidence for Private Funerary Art Production in the Ramesside Period, en: Dorn, A. y Hofmann, T. (eds.), Living and Writing in Deir el-Medine. Socio-historical Embodiment of Deir el-Medine Texts. Basilea: Schwabe, 43-55.

»Cooney, K. M. (2007). The Cost of Death. The Social and Economic Value of Ancient Egyptian Funerary Art in the Ramesside Period (Egyptologische Uitgaven series 22). Leiden: Netherlands Institute of the Near East.

"Cruz-Uribe, E. (1988). A New Look at the Adoption Papyrus, en: Journal of Egyptian Archaeology 74: 220-223.

"David, A. (2011). The $n m h$ and the Paradox of the Voiceless of the Eloquent Peasant, en: Journal of Egyptian Archaeology 97: 73-85.

》De Melo Tunes, C. M. (1990). O Modo de Produção Asiático e o Egito Antigo, en: Cardoso, C. (ed.), Modo de Produção Asiático. Nova Visita a um Velho Conceito. Río de Janeiro: Editora Campus.

»Diakonoff, I.M. (1974). Structure of Society and State in Early Dynastic Sumer (Monographs of the Ancient Near East 1/3). Los Angeles: Undena Publications.

»Diego Espinel, A. (2011). El Reino Medio, en: Parra Ortiz, J.M. (coord.), El Antiguo Egipto: Sociedad, Economía y Política. Madrid: Marcial Pons, 209-271.

»Dunn, S. (1982). The Fall and Rise of the Asiatic Mode of Production. Londres: Routledge \& Kegan Paul.

»Edgerton, W. F. (1951). The Strikes in Ramses III's Twenty-Ninth Year, en: Journal of Near Eastern Studies 10/ 3: 137-145.

》Engels, F. (1983 [1853]). Letter to Marx 6 June 1853, en: Marx and Engels Collected Works, vol. 39. Moscú: Progress Publishers.

»Engels, F. (1987 [1878]). Anti-Duhring: Herr Eugen Duhring's Revolution in Science, en: Marx and Engels Collected Works, vol. 25. Moscú: Progress Publishers.

»Engels, F. (2010 [1882]). The Frankish Period, en: Marx and Engels Collected Works, vol. 26. Londres: Lawrence \& Wishart.

»Engels, F. (1933 [1884]). El origen de la familia, la propiedad y el estado. Buenos Aires: Claridad.

"Erman, A. (1894). Life in ancient Egypt. Londres: Macmillan.

» Eyre, C. J. (1979). A “Strike” Text from the Theban Necropolis, en: Ruffle, J. et al. (eds.), Glimpses of Ancient Egypt. Studies Fairman. Warminster: Aris \& Phillips, 8o-91.

»Eyre, C. J. (1992). The Adoption Papyrus in a Social Context, en: Journal of Egyptian Archaeology 78: 207-221.

»Eyre, C. J. (1994). Feudal Tenure and Absentee Landlords, en: Allam, S. (ed.), 
Grund und Boden in Altägypten (rechtliche undsozioökonomische Verhältnisse)Akten des internationalen Symposions in Tübingen 18-20Juni 1990 (Untersuchungen zum Rechtsleben im alten Ägypten, 2). Tubinga: Selbstverlag des Herausgebers, 107-133.

»Eyre, C. J. (1999). The Village Economy in Pharaonic Egypt, en: Bowman, A.K. y Rogan, E. (eds.), Agriculture in Egypt from Pharaonic to Modern Times. (Proceedings of the British Academy 96). Oxford: Oxford University Press, 3360.

»Eyre, C. J. (2004). How relevant was Personal Status to the Functioning of the Rural Economy in Pharaonic Egypt?, en: Menu, B. (ed.), La dépendance rurale dans I'Antiquité égyptienne et proche-orientale (Bibliothèque d'Étude 140). El Cairo: Institut Français d'Archéologie Orientale, 157-186.

»Eyre, C. J. (2010). The Economy: Pharaonic, en: Lloyd, A.B. (ed.), A Companion to Ancient Egypt. Oxford: Wiley-Blackwell, 291-308.

» Faulkner, R. (1991). A Concise Dictionary of Middle Egyptian. Oxford: Griffith Institute.

» Frandsen, P. J. (1990). Editing Reality: The Turin Strike Papyrus, en: IsraelitGroll, S. (ed.), Studies in Egyptology Presented to Miriam Lichtheim. Jerusalén: Magnes Press. Hebrew University, 166-199.

» Franke, D. (1983). Altägyptische verwandtschaftsbezeichnungen im Mittleren Reich (Hamburger Ägyptologische Studien 3). Hamburgo: Verlag Borg.

"Franke, D. (1991). The Career of Khnumhotep III of Beni Hasan and the so-called "Decline of the Nomarchs", en: Quirke, S. (ed.), Middle Kingdom Studies. New Malden: SIA Publishing, 51-67.

» Franke, D. (2000). First Intermediate Period, en: Redford, D. (ed.), The Oxford Encyclopedia of Ancient Egypt. Oxford: Oxford University Press, 526-532.

» Gaballa, G.A.A. (1977). The Memphite Tomb-Chapel of Mose. Warminster: Aris \& Philipps.

» Gardiner, A.H. (1905). The Inscription of Mes: A Contribution to the Study of Egyptian Judicial Procedure, en: Sethe, K., Untersuchungen zur Geschichte und Altertumskunde Ägyptens, vol. IV/3. Leipzig: J.C. Hinrichs, 89-140.

" Gardiner, A.H. (1906). Four Papyri of the Eighteenth Dynasty from Kahun, en: Zeitschrift für Ägyptische Sprache und Altertumskunde 43: 27-47.

" Gardiner, A.H. (1940). Adoption Extraordinary, en: Journal of Egyptian Archaeology 26: 23-29.

"Gardiner, A.H. (1941). Ramesside Texts Relating to the Taxation and Transport of Corn, en: Journal of Egyptian Archaeology 27: 19-73; 127-185.

»Gardiner, A.H. (1941-1952). The Wilbour Papyrus. Londres: Oxford University Press.

» Gardiner, A.H. (1947). Onomastica, vol. II. Londres: Oxford University Press.

» Gardiner, A. H. (1948). Ramesside Administrative Documents. Oxford: Griffith Institute.

"Godelier, M. (1971). Sobre el modo de producción asiático. Buenos Aires: Quintaria.

»Godelier, M. (1977). Teoría Marxista de las sociedades precapitalistas. Barcelona: Laia. 
» Godelier, M. (1989). Lo ideal y lo material. Madrid: Taurus.

" Goedicke, H. (1970). Die Privaten Rechtsinschriften aus dem Alten Reich. Viena: Notring.

» Goedicke, H. (1984). Studies in the Hekanakhte Papers. Baltimore, Maryland: Halgo.

》 Goody, J. (1996). The East in the West. Cambridge: Cambridge University Press.

» Grajetzki, W. (2009). Court Officials of the Egyptian Middle Kingdom. Londres: Duckworth Egyptology.

» Grandet, P. (1994). Papyrus Harris I: BM 9999 (Bibliothèque d'Étude 109). El Cairo: Institut Français d'Archéologie Orientale.

» Griffith, F. L. (1889). The Inscription of Siût and Dêr Rîfeh. Londres: Trübner.

»Griffith, F. L. (1898). Hieratic Papyri from Kahun and Gurob. Londres: Bernard Quaritch.

" Habachi, L. (1985). The sanctuary of Heqaib (Elephantine 4). Mainz am Rhein: Philipp von Zabern.

" Haldon, J. (1993). The State and the Tributary Mode. Londres: Verso.

» Hall, H.R. (1924). The Middle Kingdom and the Hyksos Period, en: Bury, J. et al. (eds.), The Cambridge Ancient History, vol. I. Cambridge: Cambridge University Press: 229-325.

»Haring, B. (1997). Divine Households: Administrative and Economic Aspects of the New Kingdom Royal Memorial Temples in Western Thebes (Egyptologische Uitgaven 12). Leiden: Nederlands Instituut voor het Nabije Oosten.

" Harris, D.R. (1994). The Archaeology of V. Gordon Childe. Chicago: The University of Chicago Press.

» Hayes, W. C. (1961). The Middle Kingdom in Egypt: The Cambridge Ancient History, vol. I. Cambridge: Cambridge University Press.

" Helck, W. (1971). Die Beziehungen Ägyptens zu Vorderasien im 3. und 2. Jahrtausend v. Chr. (Ägyptologische Abhandlungen 5). Wiesbaden: Harrassowitz.

» Helck, W. (1977). Die Lehre für Merikare: kleine ägyptische Texte. Wiesbaden: Harrassowitz.

" Helck, W. (1963). Der Papyrus Berlin P.3047, en: Journal of the American Research Center in Egypt 2: 65-73.

» Hindess, B. y Hirst, P.Q. (1975). Pre-Capitalist Modes of Production. Londres: Routledge \& Kegan Paul.

»Hoffman, M. A. (1979). Egypt Before the Pharaohs. Londres: Knopf.

" James, T.G.H. (1962). The Hekanakht Papers and other early Middle Kingdom Documents. Nueva York: Publications of the Metropolitan Museum of Art Egyptian Expedition.

" Janssen, J. J. (1975). Commodity Prices from the Ramessid Period. Leiden: Brill.

" Janssen, J. J. (1979a). Background Information on the Strikes of Year 29 of Ramesses III, en: Oriens Antiquus 18: 301-308.

" Janssen, J.J. (1979b). The Role of the Temple in the Egyptian Economy during the New Kingdom, en: Lipinski, E. (ed.), State and Temple Economy in the Ancient 
Near East, Proceedings of the International Conference organised by the Katholieke Universiteit Leuven from the 1oth to the 14th of April 1978 (Orientalia Lovaniensia Analecta 6), vol. II. Lovaina: Departement Oriëntalistiek, 505-515.

"Janssen, J. (1986). Agrarian Administration in Egypt during the Twentieth Dynasty, en: Bibliotheca Orientalis 43: 351-366.

" Janssen, J. J. (1992), The Year of the Strikes, en: Bulletin de la Société d'Égyptologie de Genève 16: 41-49.

" Jones, R. (1852). Textbook of Lectures on the Political Economy of Nations. Hertford: Stephen Austin.

" Katary, S.L.D. (1989). Land Tenure in the Ramesside Period. Londres: Kegan Paul.

" Kemp, B. (1972). Temple and Town in ancient Egypt, en: Ucko, P. et al. (eds.), Man, Settlement and Urbanism. Londres: Duckworth, 657-68o.

» Kemp, B. (2018). Ancient Egypt: Anatomy of a Civilization, $3^{\underline{a}}$ ed. Nueva York: Routledge.

» Kitchen, K. A. (1979). Ramesside Inscriptions, Historical and Biographical, II. Oxford: Blackwell.

"Kitchen, K. A. (1981). Ramesside Inscriptions: Historical and Biographical, IV. Oxford: Blackwell.

» Kitchen, K. A. (1983). Ramesside Inscriptions: Historical and Biographical, VI. Oxford: Blackwell.

" Krader, L. (1972). Ethnological Notebooks of Karl Marx: (Studies of Morgan, Phear, Maine, Lubbock). Assen: Van Gorcum.

" Krader, L. (1975). The Asiatic Mode of Production: Sources, Development and Critique in the Writings of Karl Marx. Assen: Van Gorcum.

"Lacau, P. (1926). Stèles du Nouvel Empire. Catalogue général des Antiquités Égyptiennes du Musée du Cairo. El Cairo: Institut Français d'Archéologie Orientale.

"Lesko, L. H. (1994). Pharaoh's Workers: The Villagers of Deir el-Medina. Ithaca y Londres: Cornell University Press.

" Lichtheim, G. (1963). Marx and the "Asiatic mode of production", en: St. Anthony's Papers 14: 86-112.

" Lichtheim, M. (1975). Ancient Egyptian Literature [AEL], vol. I. Berkeley, University of California Press.

» Lichtheim, M. (1976). Ancient Egyptian Literature [AEL], vol. II. Berkeley, University of California Press.

»Lichtheim, M. (1988). Ancient Egyptian Autobiographies Chiefly of the Middle Kingdom: A Study and an Anthology (Orbis Biblicus et Orientalis 84). Friburgo: Universitätsverlag.

"Liverani, M. (1976). Il modo di produzione, en: Moscati, S. (ed.), L'alba della cività. Società, economia e pensiero nel Vicino Oriente antico, II. Turín: UTET, 1-126.

"Liverani, M. (1975). Communautés de village et palais royal dans la Syrie du llème millénaire, en: Journal of the Economic and Social History of the Orient 18: 146-164. 
》Loone, E. (1995). O’Leary, Marx and Asia, en: Studia Philosophica II/ 38: 88-95.

"Loprieno, A. (1988). Topos und Mimesis: Zum Ausländer in der ägyptischen Literatur. Wiesbaden: Harrassowitz.

»Loret, V. (1901). La grande inscription de Mes a Saqqarah, en: Zeitschrift für Ägyptische Sprache und Altertumskunde 29: 1-10.

"Lupo, S. (2007). Territorial Appropriation during the Old Kingdom, XXVIIIthXXIIIrd Centuries BC: The Royal Necropolises and the Pyramid Towns in Egypt. Oxford:Archaeopress.

"Lupo, S. (2011). El papel de los hijos reales en la consolidación del estado egipcio durante el Reino Antiguo: una alternativa de análisis, en: Cuadernos del Sur-Historia 39: 109-122.

" Mandel, E. (1971). The Formation of the Economic Thought of Karl Marx. Nueva York: Monthly Review Press.

» Marx, K. (1979 [1853]). The British Rule in India, en: Marx and Engels Collected Works, vol.12. Moscú: Progress Publishers.

"Marx, K. (1983 [1853]). Letter to Engels 2 June 1853, en: Marx and Engels Collected Works, vol. 39. Moscú: Progress Publishers.

" Marx, K. y Hobsbawm, E. (1984 [1965]). Formaciones económicas precapitalistas. Barcelona: Crítica.

» Marx, K. (1965 [1867]). Capital, vol. I. Moscú: Progress Publishers.

» Marx, K. (1966 [1894]). Capital, vol. III. Moscú: Progress Publishers.

» Marx, K. (1989 [1881]). Drafts of the Letter to Vera Zasulich, en: Marx and Engels Collected Works, vol. 24. Moscú: Progress Publishers.

" Mazar, A. (1990). Archaeology of the Land of the Bible 10000-586 B.C.E. Nueva York: Doubleday.

» Mc Dowell, A. (1993). Hieratic Ostraca in the Hunterian Museum Glasgow (The Colin Campbell Ostraca). Oxford: Griffith Institute.

" Mc Dowell, A. (1999). Village Life in Ancient Egypt. Oxford: Oxford University Press.

»Meeks, D. (1979). Les donations aux temples dans l'Égypte du ler millénaire avant J.C., en: Lipinski, E. (ed.), State and Temple Economy in the Ancient Near East, Proceedings of the International Conference organised by the Katholieke Universiteit Leuven from the 1oth to the 14th of April 1978 (Orientalia Lovaniensia Analecta 6), vol. II. Lovaina: Departement Oriëntalistiek, 605-687.

"Melotti, U. (1977). Marx and the Third World. Londres: MacMillan Press.

"Menu, B. (1970). Le régime juridique des terres et du personnel attaché à la terre dans le Papyrus Wilbour, 17, (Publications de la faculté des lettres et sciences humaines 1, Institut de papyrologie et di egyptologie). Lille: Faculté des lettres et sciences humaines.

» Menu, B. (1982). Le régime juridique des terres en Égypte pharaonique, en: Recherches sur l'histoire juridique, économique et sociale de l'ancienne Égypte. Versalles: $s / r$.

» Menu, B. (1998). Recherches sur l'histoire juridique, économique et sociale de l'ancienne Égypte, II (Bibliothèque d'Étude 122). El Cairo: Institut Français d'Archéologie Orientale. 
》Menu, B. (2004). Égypte pharaonique. Nouvelles recherches sur l'histoire juridique, économique et sociale de l'ancienne Égypte. París: L'Harmattan.

»Menu, B, y Harari, I. (1974). La notion de propriété privée dans l'Ancien Empire égyptien, en: Cahier de recherches de l'Institut de papyrologie et d'égyptologie de Lille 2: 125-154.

"Moreno García, J. C. (1994). Hwt y la retribución de los funcionarios provinciales en el Imperio Antiguo: el caso de Jbj de Deir el-Gebrawi (Urk.I 144:3-145:3), en: Aula Orientalis 12: 29-50.

» Moreno García, J. C. (1996). Hwt et le milieu rural égyptien du Ille millénaire, en: Zeitschrift für Agyptische Sprache und Altertumskunde 23:116-138.

" Moreno García, J.C. (1998). La population mrt: Une approche du problème de la servitude dans l'Égypte du Ille millénaire(I), en: The Journal of Egyptian Archaeology 84: 71-83.

» Moreno García, J. C. (2001). L'organisation sociale de l'agriculture dans l'Egypte pharaonique pendant l'ancien empire (2650- 2150 avant j.-c.), en: Journal of the Economic and Social History of the Orient 44/4: 411-450.

» Moreno García, J.C. (2004a). Egipto en el Imperio Antiguo [2650-2150 antes de Cristo]. Barcelona: Bellaterra.

" Moreno García, J.C. (2004b). Elites y Agricultura Institucional: el papel de los templos provinciales egipcios durante el Imperio Antiguo, en: Huelva Arqueológica 19: 27-55.

» Moreno García, J.C. (2008). Review Article La dépendance rurale en Égypte ancienne, en: Journal of the Economic and Social History of the Orient 51: 99-150.

» Moreno García, J. C. (2011a). El Primer Período Intermedio, en: Parra Ortiz, J.M. (coord.), El Antiguo Egipto: Sociedad, Economía y Política. Madrid: Marcial Pons, 181-208.

»Moreno García, J. C. (2011b), Les mnhw: société et transformations agraires en Égypte entre la fin du lle et le début du ler millénaire, en: Revue d'Égyptologie 62: 105-114.

" Moret, A. (1901). Un procès de famille sous la XIXe dynastie, en: Zeitschrift für Ägyptische Sprache und Altertumskunde 29: 11-39.

» Morgan, L.H. (1877). Ancient Society. Londres: MacMillan \& Company.

» Namboodiripad, E.M.S. (1952). The National Question in Kerala. Bombay: Peoples Publishing House.

» Namboodiripad, E.M.S. (2010). Marx, the Asiatic Mode and the Study of Indian History, en: History, Society and Land Relations. Nueva Delhi: Left Word Books, 23-31.

» Navailles, R. y Neveu, F. (1989). Qu'entendait-on par 'journée d'esclave' au Nouvel Empire? ( $h r w m$ hm(t), hrw n b3k), en: Revue d'Égyptologie 40: 113-123.

»Naville, E. (1896). The Temple of Deir el Bahari, II. Londres: Egypt Exploration Fund.

"O'Connor, D. (1972). The Geography of settlement in ancient Egypt, en: Ucko, P., et al. (eds.), Man, Settlement and Urbanism. Londres: Duckworth, 692-695.

"O'Leary, B. (1989). Marx and Engels on the Asiatic Mode of Production and India, en: O'Leary, B. (ed.), The Asiatic Mode of Production: Oriental Despotism, 
Historical Materialism, and Indian History. Oxford y Nueva York: Basil Blackwell, 82-151.

»Papazian, H. (1999). The "Per Shena": From Palace Estate to Sacred Storehouse. The Structure and Evolution of an Ancient Egyptian Economic Institution (A Dissertation Proposal Presented to The Department of Near Eastern Languages and Civilizations, The Department of Near Eastern Languages and Civilizations). Chicago: The University of Chicago.

»Papazian, H. (2012). Domain of Pharaoh: the structure and components of the economy of Old Kingdom Egypt. Hildesheim: Gerstenberg.

»Parkinson, R. (2002). Poetry and culture in Middle Kingdom Egypt: a dark side to perfection. Londres: Continuum.

»Parra Ortiz, J.M. (2011). El Reino Antiguo, en: Parra Ortiz, J.M. (coord.), El Antiguo Egipto: Sociedad, Economía y Política. Madrid: Marcial Pons, 125-180.

»Petrie, W.M.F. (1925). Tombs of the Courtiers and Oxyrhynkhos. Londres: British School of Archaeology in Egypt.

»Piacentini, P. (1994). Titles of the HqAw Hwt, en: Allam, S. (ed.), Grund und Boden in Altägypten (rechtliche undsozioökonomische Verhältnisse)- Akten des internationalen Symposions in Tübingen 18-20 Juni 1990 (Untersuchungen zum Rechtsleben im alten Ägypten, 2). Tubinga: Selbstverlag des Herausgebers, 235249.

》Pleyte, W. y Rossi, F. (1869-76). Papyrus de Turin, 2 vols. Londres, S. Birch.

»Polanyi, K. et al. (1957). Trade and Market in the Early Empires, Economies in History and Theory. Illinois: The Free Press.

»Posener, G. (1956). Littérature et politique dans l'Égypte de la XIle dynastie (Bibliothèque de l'Ecole des Hautes Etudes 307). París: Champion.

»Posener-Krieger, P. (1975). Les papyrus de Gébélein. Remarques Préliminaires, en: Revue d'Egyptologie 27: 211-221.

»Redford, D.B. (1993). Egypt, Canaan and Israel in Ancient Times. El Cairo: The American University in Cairo Press.

» Richards, J. (2005). Society and Death in Ancient Egypt: Mortuary Landscapes of the Middle Kingdom. Cambridge: Cambridge University Press.

» Roeder, G. (1913). Aegyptische Inschriften aus den königlichen Museen zu Berlin. Leipzig: Hinrichs.

» Römer, M. (1994). Gottes- und Priesterherrschaft in Ägypten am Ende des Neuen Reiches: Ein religionsgeschichtliches Phänomen und seine sozialen Grundlagen. Wiesbaden: Harrassowitz.

» Roth, A.M. (1991). Egyptian Phyles in the Old Kingdom. The Evolution of a System of Social Organization. Chicago: The Oriental Institute of the University of Chicago.

" Ryholt, K. (1997). The Political Situation in Egypt during the Second Intermediate Period c.1800-1550 B.C. (Carsten Niebuhr Institute Publications 20). Copenhague: Museum Tuscalanum Press.

» Said, E. W. (1977). Orientalism. Londres: Penguin.

"Sawer, M. (1977). Marxism and the Question of the Asiatic Mode of Production. La Haya: Martinus Nijhoff.

"Schulman, A.R. (1964). Military Rank, Title and Organization in the Egyptian New 
Kingdom. Berlín: Hessling.

"Schulman, A.R. (1988). Ceremonial execution and public rewards: some historical scenes on New Kingdom private stelae (Orbis biblicus et orientalis, 75). Gotinga: Vandenhoeck \& Ruprecht.

"Seidl, E. (1939). Einführung in die ägyptische Rechtsgeschichte bis zum Ende des neuen Reiches (Ägyptologische Forschungen 10). Glückstadt: Augustin.

"Seidlmayer, S. (1990). Gräberfelder aus dem Übergang vom Alten zum Mittleren Reich (Studien zur Archäologie der Ersten Zwischenzeit 1). Heidelberg: Heidelberger Orientverl.

》Seidlmayer, S. (2007 [2000]). El Primer Periodo Intermedio, en: Shaw, I. (ed.), Historia del Antiguo Egipto. Madrid: La Esfera de los libros, 159-195.

»Serrano Delgado, J. M. (1993). Textos para la Historia antigua de Egipto. Madrid: Cátedra.

"Smither, P.C. (1948). The Report concerning the slave-girl Senbet, en: Journal of Egyptian Archaeology 34: 31-34.

»Sofri, G. (1969). Il modo di produzione asiatico. Storia di una controversia marxista. Turín: Einaudi.

"Soriano Llopis, I. (2007). La formación del Estado en el Valle Medio del Río Amarillo. Un acercamiento teórico y práctico a los inicios de la Edad del Bronce en China. Investigación de Maestría en Arqueología prehistórica no publicada (MRes). Barcelona: Universidad Autónoma de Barcelona.

»Spalinger, A. (1984). The Will of Senimose, en: Junge, F. (ed.), Studien zu Sprache und Religion Ägyptens Zu Ehren von Wolfhart Westendorf überreicht von seinen Freunden und Schülern,vol. 1. Gotinga: Hubert.

"Spiegelberg, W. (1897).The Inscriptions, en: Petrie, W.M.F., Six Temples at Thebes. Londres: Quaritch, 1-25, pls. 13-14.

» Spiegelberg, W. (1904). Varia. LXXVII: Zu whj-t "stamm, ansiedelung”, en: Recueil de Travaux 26: 143-154.

»Steindorff, G. (1935). Aniba: Mission archéologique de Nubie, II. Hamburgo: J.J. Augustin.

"Strudwick, N. (2005). Texts from the Pyramid Age (Writing from the Ancient World 16). Atlanta: Society of Biblical Literature.

"Struve, V. (1965). The Concept of the Asian Mode of Production, en: Soviet Anthropology and Archeology 4/2: 41-46.

» Suret-Canale, J. (1961). L’Afrique Noire. París: Éditions Sociales.

»Suret-Canale, J.(1964). Les societés traditionelles en Afrique noire et le concept du mode de production asiatique, en: La Pensée 177: 19-22.

»Tan, J.B. (2000). Marx, historical materialism and the asiatic mode of production. Tesis presentada en cumplimiento parcial de los requisitos para el grado de Maestría en artes en la Escuela de comunicación. Vancouver: Simon Fraser University.

"Théodoridès, A. (1965). Le Papyrus de Adoptions, en: Revue Internationale des Droits de l'Antiquité 12: 79-142.

»Théodoridès, A. (1966). Le “testament" de Naunakhte, en: Revue Internationale des Droits de l'Antiquité 13: 31-70. 
» Thédoridès, A. (1968). Procès relatif à une vente qui devait être acquittée par la livraison d'un travail servile (Papyrus Berlin 9785), en: Revue Internationale des Droits de l'Antiquité 15: 39-104.

»Thédoridès, A. (1970). Le testament dans l'Égypte ancienne (essentiellement d'après le papyrus Kahoun VII; la Stèle de Senimose et le Papyrus Turin 2021), en: Revue Internationale des Droits de l'Antiquité 17: 137-147.

" Troy, L. (2002 [1998]). Resource Management and Ideological Manifestation. The Towns and Cities of Ancient Egypt, en: Development of Urbanism from a Global Perspective. Uppsala: Uppsala Universiteit, 1-58.

»Urk. I. Sethe, K. H. (1933). Urkunden des Alten Reichs. Leipzig: J.C. Hinrichs.

»Urk. IV. Sethe, K. H. (1906-9). Urkunden der 18. Dynastie, Urkunden des ägyptischen Altertums. Leipzig: J.C. Hinrichs.

"Vandier, J. (1950). Mo'alla: La tombe d'Ankhtifi et la tombe de Sebekhotep (Bibliothèque d'Étude, 18). El Cairo: Institut Français d'Archéologie Orientale.

»Varille, A. (1935-89). La Stèle de Sa-Mentou-ouser, en: Mélanges Maspero vol. 1/2 (Mémoires d'l'Institut Français d'Archéologie Orientale 66). El Cairo: Institut Français d'Archéologie Orientale, 553-566.

»Vidal-Naquet, P. (1964). Histoire et idéologie: Karl Wittfogel et le concept de " mode de production asiatique ", en: Annales. Économies, Sociétés, Civilisations 19/ 3: 531-549.

»Visacovsky, S.E. y Garguin, E. (2009). Introducción, en: Moralidades, economías e identidades de clase Media. Buenos Aires: Antropofagia, 11-59.

» von Beckerath, J. (1965). Untersuchungen zur politischen Geschichte der zweiten Zwischenzeit in Ägypten (Ägyptologische Forschungen 23). Glückstadt: J.J. Augustin.

»Wb Erman, A. y Grapow, H. (1971). Wörterbuch der ägyptischen Sprache, 6 vols. Berlín: Akademie-Verlag.

"Wente, E.F. (1990). Letters from ancient Egypt. Atlanta: Scholars Press.

"Wickham, Ch. (1994a [1984]), The Other Transition: From the Ancient World to Feudalism, en: Land and Power: Studies in Italian and European Social History, 400-1200. Londres: British School at Rome, 7-42.

» Wickham, Ch. (1994b [1985]). The Uniqueness of the East, en: Land and Power: Studies in Italian and European Social History, 400-1200. Londres: British School at Rome, 43-75.

»Willems, H. (2010). The First Intermediate Period and the Middle Kingdom, en: Lloyd, A. B. (ed.), A Companion to Ancient Egypt. Oxford: Wiley-Blackwell, 81100.

»Wilson, J. (1951). The Burden of Egypt. Chicago: Chicago University Press.

»Winlock, H.E. (1922). Excavations at Thebes, en: The Metropolitan Museum of Art Bulletin, vol. 17, 12/ 2: The Egyptian Expedition, MCMXXI-MCMXXII: 19-49.

»Wittfogel, K. (1966 [1957]). Despotismo Oriental. Estudio comparativo del poder totalitario. Madrid: Guadarrama.

"Zaccagnini, C. (1989). Asiatic Mode of Production and Ancient Near East. Notes Towards a Discussion, en: Zaccagnini, C. (ed.), Production and Consumption. Budapest: Egyptological Department, University of Budapest: 1-126. 
»Zamora, J.A. (1997). Sobre "el modo de producción asiático" en Ugarit. Madrid y Zaragoza: Consejo Superior de Investigaciones Científicas e Institución "Fernando el Católico".

"Zingarelli, A.P. (2010). Introducción Dossier: Mito, literatura y política en el Egipto antiguo, en: Trabajos y Comunicaciones 36: 207-230.

"Zingarelli, A.P. (2010). Trade and Market in New Kingdom Egypt. Oxford: Archaeopress.

"Zingarelli, A.P. (2015). Comments on the Egyptian term wHyt: A family quasi-village?, en Kousoulis, P. y Lazaridis, N. (eds.), Proceedings of the Tenth International Congress of Egyptologists, University of the Aegean, Rhodes, 22-29 May 2008 (Orientalia Lovaniensia Analecta 241). Lovaina: Peeters Publishers, 909-920.

»Zingarelli, A.P. (2017). Huelgas de trabajadores en el Imperio Nuevo egipcio, en: Astarita, C., García Mac Gaw, C., y Zingarelli, A. (eds.), Conflictos sociales en la antigüedad y el feudalismo. El conflicto social precapitalista. La Plata: Edulp, 53-62.

"Zivie, Ch. (1976). Giza au deuxième millénaire (Bibliothèque d’Étude 70). El Cairo: Institut Français d'Archéologie Orientale. 